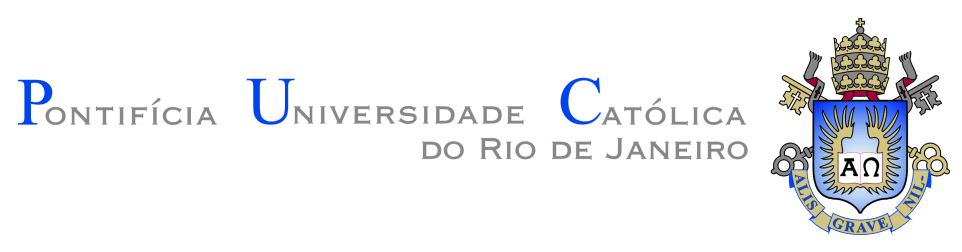

Rafaela Bianca Pini Rizzo

International Reserves and the Equity Premium

Dissertação de Mestrado

Dissertation presented to the Programa de Pós-graduação em Economia of PUC-Rio in partial fulfillment of the requirements for the degree of Mestre em Economia.

Advisor : Prof. Carlos Viana de Carvalho Co-advisor: $\quad$ Prof. Eduardo Zilberman 


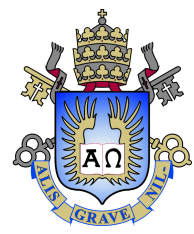

Rafaela Bianca Pini Rizzo

\title{
International Reserves and the Equity Premium
}

Dissertation presented to the Programa de Pós-graduação em Economia of PUC-Rio in partial fulfillment of the requirements for the degree of Mestre em Economia. Approved by the Examination Committee:

\author{
Prof. Carlos Viana de Carvalho \\ Advisor \\ Departamento de Economia - PUC-Rio
}

Prof. Eduardo Zilberman

Co-advisor

Departamento de Economia - PUC-Rio

Prof. Márcio Gomes Pinto Garcia

Departamento de Economia - PUC-Rio

Prof. Bernardo Guimarães

Departamento de Economia - FGV/EESP

Rio de Janeiro, August the 30th, 2021 
All rights reserved.

\section{Rafaela Bianca Pini Rizzo}

B.A., Economics, Universidade Federal do Rio de Janeiro (UFRJ), 2019.

Bibliographic data

Pini Rizzo, Rafaela Bianca

International Reserves and the Equity Premium / Rafaela Bianca Pini Rizzo; advisor: Carlos Viana de Carvalho; coadvisor: Eduardo Zilberman. - 2021.

48 f: il. color. ; $30 \mathrm{~cm}$

Dissertação (mestrado) - Pontifícia Universidade Católica do Rio de Janeiro, Departamento de Economia, 2021.

Inclui bibliografia

1. Economia - Teses. 2. Economia Internacional - Teses. 3. Macroeconomia - Teses. 4. Reservas Internacionais - Teses.

5. Equity Premium Puzzle - Teses. 6. Default Soberano - Teses. 7. Reservas Internacionais. 8. Equity Premium Puzzle. 9. Default Soberano. I. Viana de Carvalho, Carlos. II. Zilberman, Eduardo. III. Pontifícia Universidade Católica do Rio de Janeiro. Departamento de Economia. IV. Título. 


\section{Acknowledgments}

I thank God for holding me in the difficult times and guiding my family. I thank my mother, Jorgelene, for the endless love and tireless support during my entire life. I thank my grandmother, Lenir, who is the inspiration and the brightness in my life. I would not be who I am today if it weren't for their love, dedication and strength.

I have no words to thank my advisor, Prof. Carlos Viana de Carvalho, for his incredible guidance, support and constant dedication to this project. I am also grateful to my co-advisor, Prof. Eduardo Zilberman, for his helpful insights, support and understanding.

I would like to thank my classmates, who made this journey much more exciting and enriching with brilliant discussions. And, of course, I am grateful to all the department at PUC-Rio, brilliant teachers who inspired me and enhanced my knowledge to another level.

This study was partly financed by the Coordenação de Aperfeiçoamento de Pessoal de Nível Superior - Brasil (CAPES) - Finance Code 001 and the Conselho Nacional de Desenvolvimento Científico e Tecnológico - CNPq. The financial supports from PUC-Rio and Vinci Partners are also gratefully acknowledged. 


\section{Abstract}

Pini Rizzo, Rafaela Bianca; Viana de Carvalho, Carlos (Advisor); Zilberman, Eduardo (Co-Advisor). International Reserves and the Equity Premium. Rio de Janeiro, 2021. 48p. Dissertação de Mestrado - Departamento de Economia, Pontifícia Universidade Católica do Rio de Janeiro.

Insurance is a possible explanation for the large holdings of international reserves observed in many countries. Quantitative models of the insurance motive, however, struggle to rationalize reserve positions, unless agents exhibit relatively high levels of risk aversion. This result suggests a connection between the international reserves puzzle and the equity premium puzzle, which we explore in this paper. We introduce Epstein-Zin preferences into a standard sovereign default model with long-term debt and a risk-free asset, and calibrate it to the Mexican economy. We then price an equity claim within the model, and use simulations to establish a positive relationship between optimal reserve holdings and the equity premium, as we vary the degree of risk aversion of domestic agents. Using an estimate of the equity premium for Mexico, we calibrate the level of risk aversion and find it produces an optimal level of international reserves that is close to the data. Finally, we provide empirical evidence consistent with the relationship established with the model. Specifically, we introduce estimates of the equity premium into standard regressions used to explain countries' holdings of international reserves. Using both cross-sectional and panel specifications, we document a robust positive association between these two variables.

\section{Keywords}

International Reserves; Equity Premium Puzzle; Sovereign Default. 


\section{Resumo}

Pini Rizzo, Rafaela Bianca; Viana de Carvalho, Carlos; Zilberman, Eduardo. Reservas Internacionais e o Equity Premium. Rio de Janeiro, 2021. 48p. Dissertação de Mestrado - Departamento de Economia, Pontifícia Universidade Católica do Rio de Janeiro.

Uma possível razão para a alta acumulação de reservas internacionais observada em diversos países está relacionada à vontade de se assegurar contra eventuais crises. Os modelos quantitativos de seguro, entretanto, possuem dificuldade para racionalizar as posições de reserva, a menos que os agentes exibam níveis relativamente altos de aversão ao risco. Esse resultado sugere uma conexão entre o "puzzle" de reservas internacionais e o "equity premium puzzle", que exploramos nesta dissertação. Introduzimos preferências EpsteinZin em um modelo padrão de default soberano com dívida de longo prazo e um ativo livre de risco, e o calibramos para a economia mexicana. Em seguida, precificamos um ativo de ação dentro do modelo e usamos simulações para estabelecer uma relação positiva entre o nível ótimo de reservas e o "equity premium", conforme variamos o grau de aversão ao risco dos agentes domésticos. Usando uma estimativa do "equity premium" para o México, calibramos o nível de aversão ao risco e encontramos um nível ótimo de reservas internacionais próximo aos dados. Por fim, fornecemos evidência empírica consistente com a relação estabelecida no modelo. Especificamente, introduzimos estimativas do "equity premium" e, usando especificações "crosssectional" e de painel, documentamos uma associação positiva e robusta entre essas duas variáveis.

\section{Palavras-chave}

Reservas Internacionais; Equity Premium Puzzle; Default Soberano. 


\section{Table of contents}

1 Introduction 11

2 The Model $\quad 16$

2.1 Recursive Government Problem 17

$\begin{array}{lll}2.2 & \text { Recursive Equilibrium } & 19\end{array}$

2.3 The Equity Premium 19

3 Quantitative Analysis $\quad 22$

3.1 Calibration 22

$\begin{array}{lll}3.2 & \text { Results } & 25\end{array}$

3.2.1 Comparative Statics 26

$4 \quad$ Empirical Evidence $\quad 29$

$\begin{array}{lll}4.1 & \text { Data } & 29\end{array}$

4.2 Panel Regressions 30

4.3 Pure Cross-Section Regressions 32

5 Conclusion $\quad 35$

A Cross-Section Data $\quad 41$

B Panel Regressions $\quad 42$

C Panel Regressions in Restricted Sample 45 


\section{List of figures}

Figure 1.1 International Reserves and Equity Premium 13

Figure 3.1 Model Simulations and Data 28

Figure C.1 International Reserves and Equity Premium - All Countries 45 


\section{List of tables}

Table 3.1 Calibration 23

Table 3.2 Targeted Moments, in \% 24

Table 3.3 Internal Calibration for the Comparative Statics 25

Table 3.4 Results for Mexico, in \% 26

Table 3.5 Comparative Statics for Mexico, in \% 27

Table 4.1 Summary Statistics, in \% 30

Table 4.2 Panel Pooled OLS Regressions, 3 windows 32

Table 4.3 Pure Cross-Section Regressions 33

Table A.1 Cross-Section Data - Average from 2000 to 2018, in \% 41

Table B.1 Panel Fixed Effect Regressions with Annual Data 42

Table B.2 Panel Fixed Effect Regressions with 2 windows 43

Table B.3 Panel Pooled OLS Regressions with 2 windows 43

Table B.4 Panel Fixed Effect Regressions with 3 windows 44

Table C.1 Panel Fixed Effect Regressions with Annual Data excluding outliers 46

Table C.2 Panel Fixed Effect Regressions with 3 windows excluding outliers 46

Table C.3 Panel Pooled OLS Regressions with 3 windows excluding outliers

Table C.4 Panel Fixed Effect Regressions with 2 windows excluding outliers

Table C.5 Panel Pooled OLS Regressions with 2 windows excluding outliers

Table C.6 Pure Cross-Section Regressions excluding outliers 48 


\section{List of Abreviations}

AR(1) - Autoregressive process of order 1

BRA - Brazil

CDS - Credit Default Swap

CRRA - Constant relative risk aversion

EMBI+ - Emerging Market Bond Index Plus

EIS - Elasticity of intertemporal substitution

FED - Federal Reserve Bank of United States

FRED St. Louis - Federal Reserve Economic Data of Saint Louis

FX - Foreign Exchange

GDP - Gross domestic product

IFS - International Financial Statistics

IMF - International Monetary Fund

M2 - Monetary aggregate

MEX - Mexico

MSCI - Morgan Stanley Capital International

NBER - National Bureau of Economic Research

OLS - Ordinary Least Squares

p.p. - percentage points

SDF - Stochastic Discount Factor

Std. Dev. - Standard deviation

U.S. - United States of America 


\section{Introduction}

Emerging market economies tend to hold large amounts of international reserves as a hedge against disruptions in international financial markets. However, reserve assets are also costly, since they could be used to lower debt levels, sovereign spreads and risk. Although there is a large and growing literature that addresses questions related to the optimal level of international reserves, quantitative models struggle to rationalize optimal positions consistent with data. The excess of reserve accumulation could be driven by agents with a strong desire for self-insurance against financial crises, exhibiting a high level of risk aversion. ${ }^{1}$ An increase in the risk aversion also indicates a higher level of the equity premium for the economy, ${ }^{2}$ which suggests a correspondence with the reserves puzzle.

This dissertation studies the connection between the optimal level of international reserves and the equity premium puzzles. The equity premium, which is the difference between equity and risk-free bond returns, requires high levels of risk aversion in asset pricing models to generate a premium consistent empirically. Then, since both empirical levels of international reserves and equity premium are above the optimal levels found by most of the quantitative models, they constitute a puzzle. The quantitative approach to generate the observed equity premium is to augment the risk aversion of domestic agents, which is consistent with the reserves puzzle, revealing a desire for insurance. We, then, simulate a canonical model of sovereign default in an incomplete markets framework with international reserves and long-term debt, based on Bianchi et al. (2018) and Arellano (2008), disciplining by the equity premium. In order to study the effect of the risk aversion on the choice of reserves by the government, without any interference of the elasticity of intertemporal substitution, we introduce Epstein-Zin preferences (Epstein and Zin (1989); Weil (1989)) in the sovereign debt model. By targeting the equity premium, we can compare the corresponding observed and simulated levels of reserves

\footnotetext{
${ }^{1}$ Although this dissertation focus on an insurance motive to accumulate international reserves, there are studies that analyze other motivating factors. See Heller (1966), Frenkel and Jovanovic (1981), Obstfeld et al. (2010), Benigno and Fornaro (2012) and Samano (2020).

${ }^{2}$ See Mehra and Prescott (1985) and Weil (1989).
} 
for the economy.

In the model, the government is subject to rollover risk, which is the risk of having to roll over its debt obligations at times when its borrowing opportunities deteriorate. The government transfers resources from good times to bad times by accumulating reserves and long-term debt, providing a hedge against rollover risk and financial crises. The more the domestic agents are risk averse, the more they desire to self-insure against bad times, increasing the incentives to accumulate reserves. More risk-averse agents tend to induce the government to accumulate larger amounts of international reserves, while the economy presents a higher level of equity premium. However, it is costly since the government could reduce spreads by paying down debt using the reserves. This is the main trade-off of our model.

We simulate the model for Mexico. Mexican business cycle displays the same properties that are observed in other emerging economies, however its reserves-to-GDP level is much lower than the average for other countries, as discussed further in Chapter 4. We calibrate the model by targeting specific moments of the economies, including the equity premium. Model simulations confirm that an economy with a higher equity premium tends to hold more international reserves. The exercise for Mexico generated an average level of reserves-to-income of $12.7 \%$, which is consistent with Mexican data from 2000 to 2018 , and an equity premium of $4.8 \%$, close to its target of $4.9 \%$.

In order to document the quantitative importance of the equity premium in our results, we present a comparative statics for Mexico and show that increasing the risk aversion parameter from 3.3 to 15.0 the reserves-to-income level augments 6.7 percentage points in a period of a year, going from $6.0 \%$ to $12.7 \%$, while the leveraged equity premium increases from $0.3 \%$ to $4.8 \%$. Hence, model simulations confirm the connection between the puzzles, since higher levels of risk aversion increases both the equity premium and the optimal level of international reserves in the economy. The Epstein-Zin preferences enabled the calibration of the risk aversion in separate from the elasticity of intertemporal substitution, not affecting the consumption smoothing of the agents. Note that we are not claiming that the risk aversion is the explanation for the both puzzles, but it is a mechanism that suggests a correlation between reserves and equity premium, which we find in the data.

Then, besides the quantitative relationship between international reserves and equity premium, we also study the empirical interaction between the puzzles using data for 42 countries from 2000 to 2018. Figure 1.1 shows the average ratio of reserves-to-GDP and the equity premium for each country in 
our sample, excluding outliers. ${ }^{3}$ The average of reserves-to-GDP ratio for this sample is $14.7 \%$, which is associated with a mean equity premium of $4.7 \%$. Note that the following graphic shows a clear positive relationship between reserves and equity premium.

Figure 1.1: International Reserves and Equity Premium

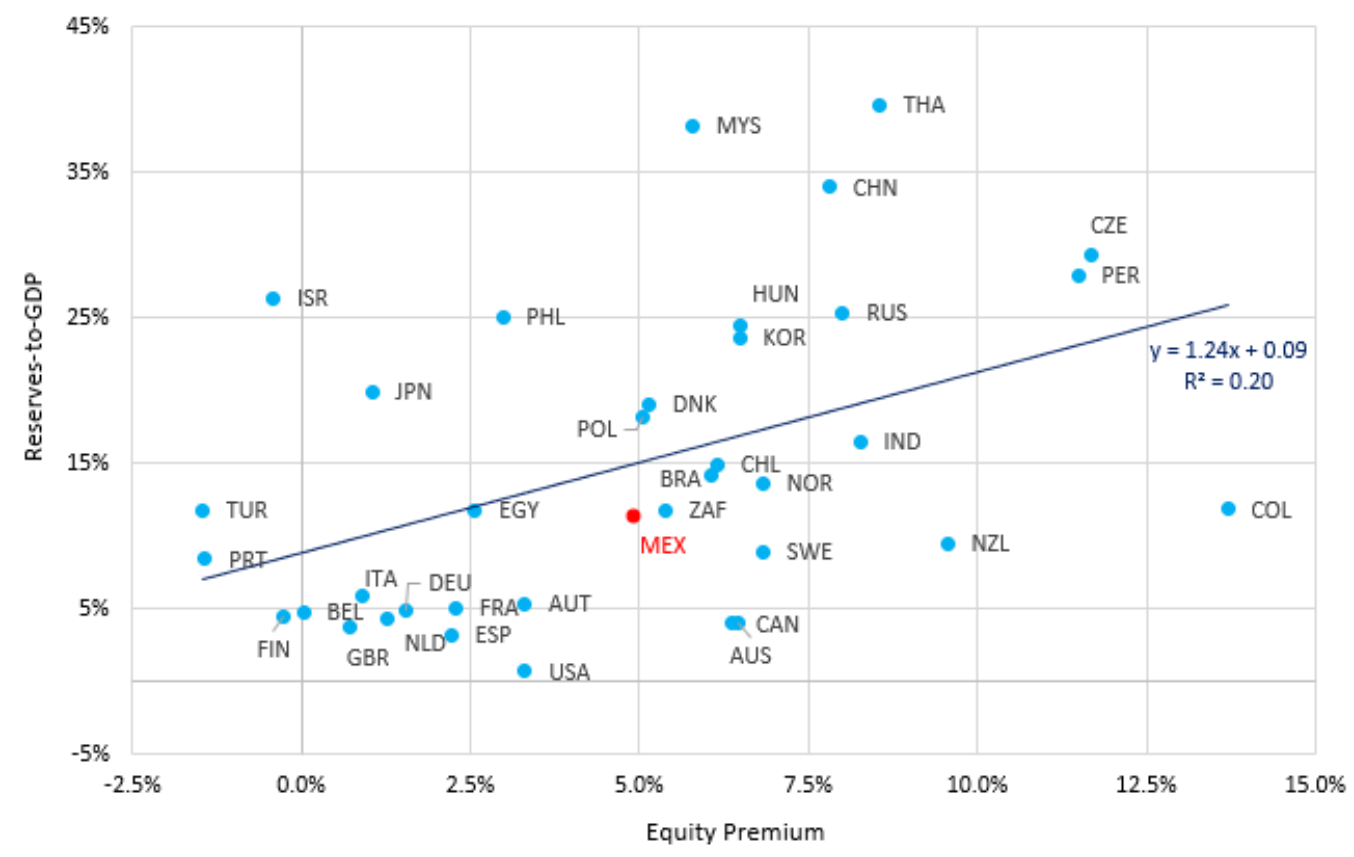

In Chapter 4, we estimate panel regressions for reserves controlling for the equity premium and other confounding factors, as the ratio of debt to GDP, the openness degree, the cyclical component of GDP, the ratio of M2 to GDP and the exchange rate regime. We estimate the regressions for panels with annual data, for windows of 6 and 9 years in order to capture the equity premium of each country, and for a pure cross-country database.

The results show a positive and significant correlation between international reserves and equity premium in each specification, including in the pure cross section, which means that serial correlation is not driving the results or generating spurious-regression effects. The main finding is that, other things equal, countries with a higher equity premium tend to accumulate more reserves, which is robust to several controls and specifications. Note that it is also consistent with our quantitative model simulations.

This dissertation contributes to several strands of the literature. Our main contribution concerns the association between the international reserves

${ }^{3}$ The outliers are Greece, Hong Kong, Ireland, Singapore and Switzerland. In Section A of the Appendix, we display the average levels of reserves and equity premium from 2000 to 2018 for all the countries used in our sample. 
and the equity premium puzzles, in which we find this connection in both the quantitative and empirical analysis. We build on the quantitative sovereign default literature that follows Aguiar and Gopinath (2006) and Arellano (2008). They show that predictions of the sovereign default model are consistent with several features of emerging markets, including counter-cyclical spreads and pro-cyclical borrowing. Arellano (2008) models an endogenous default risk, which is related with output and debt, while Aguiar and Gopinath (2006) studies alternative borrowing motives and bailouts. We present a model with long-term debt and shocks to the lenders' risk aversion and we allow governments to simultaneously accumulate assets and liabilities. We show that our model simulations are able to generate a level of reserves consistent with indebted governments.

Alfaro and Kanczuk (2009) study the joint accumulation of international reserves and sovereign defaultable debt with one-period bonds. They find that reserve accumulation does not play a quantitatively important role in their model and, hence, the optimal policy would be not to hold reserves at all. As in Bianchi et al. (2018) and in our model, reserves are used as a hedge against rollover risk, playing an insurance role that arises only when debt maturity exceeds one period. Using long-term debt in the model allows the government to transfer resources from states with low borrowing costs to states with high borrowing costs, which stimulates reserve accumulation.

The decision problem faced by the government in our model is based on Bianchi et al. (2018), which simulate a sovereign debt model with international reserves and long-term debt for the Mexican economy. We introduce EpsteinZin preferences in the sovereign default model and study the association of the optimal level of reserves with the equity premium. We show that a higher risk aversion generates an incentive to hold more reserves in order to self-insure against financial crises.

Alfaro and Kanczuk (2019) show that issuing domestic debt while accumulating reserves acts as a hedge against external shocks, as in our model. Their quantitative exercise for the Brazilian economy suggests that this strategy is effective for smoothing consumption and reducing the occurrence of default. Again, our contribution is to introduce the equity premium as a targeted moment in the sovereign debt model and analyze its interaction with the optimal level of reserves. Bianchi and Sosa-Padilla (2020) studies the accumulation of reserves in a sovereign default model with nominal rigidities under a fixed exchange rate. They show that the benefit of holding international reserves is to provide macroeconomic stability, since the government can reduce the volatility of unemployment by issuing debt to accumulate reserves. 
Both papers analyze the role of international reserves as an insurance, which is consistent with our association with the equity premium puzzle. Risk-averse agents tend to require a much higher return for the risky asset in relation to the risk-free bond to compensate the risk. The analogy with the international reserves is enabled because risk-averse agents have a desire for insurance against risk, which, in the case of sovereign debt models, include financial crises and default risks. Then, this dissertation also relates to the vast asset pricing literature.

We simulate the equity premium in our sovereign default model following Lucas (1978). Mehra and Prescott (1985) show that the large differential in the average yields cannot be accounted by models that abstract from transactions costs, liquidity constraints and other frictions absent in the Arrow-Debreu setup. Using U.S. data from 1889 to 1978, they find an equity premium of $6.18 \%$ and show that it requires a risk aversion higher than 10 to generate the observed equity premium with CRRA preferences.

However, using CRRA preferences, even if we set a high value for the risk aversion, it would imply an increase in the risk-free return, which would not be consistent with data. This phenomenon, which is the risk-free rate puzzle, was solved by Weil (1989) by introducing Epstein-Zin preferences into the asset pricing framework. These preferences generalize the time-additive and isoelastic expected utility specification to allow an independent calibration of attitudes toward risk and intertemporal substitution. The coefficient of relative risk aversion is unrelated to the intertemporal elasticity of substitution in this framework. Then, we can calibrate the risk aversion to match the equity premium without affecting the return of the risk-free bond.

Other studies seeking to explain the demand for international reserves include the literature on precautionary savings and sudden stops. Jeanne and Ranciere (2011) present an analytical formula to quantify the optimal amount of reserves and Aizenman and Lee (2007) study reserve accumulation in an endogenous sudden stops framework.

The dissertation proceeds as follows. Chapter 2 describes the sovereign default model and the subsequent chapter presents the computation method, the calibration and the results generated by model simulations. Chapter 4 presents the empirical evidence and Chapter 5 concludes. 


\section{2}

\section{The Model}

This chapter describes a dynamic small open economy in an incomplete markets framework, following Bianchi et al. (2018), in which the only state contingency spanned by the asset markets is through the option to default. The government receives a stochastic endowment stream, issues non-contingent defaultable debt and buys a risk-free reserve asset.

The stochastic endowment $y_{t}$ follows a Markov process, which is given by:

$$
\log \left(y_{t}\right)=(1-\rho) \mu+\rho \log \left(y_{t-1}\right)+\epsilon_{t},
$$

where $|\rho|<1, \epsilon_{t} \sim N\left(0, \sigma_{\epsilon}^{2}\right)$ and time is discrete $t \in\{0,1, \ldots\}$.

The timing of the economy is as follows. At $t$, the government has liabilities $b_{t}$ and reserve assets $a_{t}$. It observes the endowment shock, $y_{t}$, and the risk-premium shock, $\kappa_{t}$, and then decides whether to repay $b_{t}$ or to default on it. If it repays, then it issues new bonds $b_{t+1}$ at a price $q\left(a_{t+1}, b_{t+1}, s_{t}\right)$, accumulates new reserve assets at a price $q_{a}$ and enjoys utility given by $V^{R}\left(a_{t}, b_{t}, s_{t}\right)$, where $s_{t}=\left\{y_{t}, \kappa_{t}\right\}$ is the current exogenous state of the world. If it defaults, then the economy is excluded from debt markets in the period of default, suffers a utility loss $U^{D}\left(y_{t}\right)$ and enjoys a deviation utility $V^{D}\left(a_{t}, s_{t}\right)$. Note that the government accumulates international reserves upon default or not.

When the government defaults, it does so on all current and future debt obligations, which is consistent empirically and is a standard assumption in the literature. ${ }^{1}$ As in Bianchi et al. (2018), we assume that the recovery rate for debt in default, i.e., the fraction of the loan that lenders recover after a default, is zero. The utility loss suffered in the period of default can be viewed as a default cost related to reputation, sanctions and misallocation of resources. It is given by the following formulation:

$$
U^{D}\left(y_{t}\right)=\alpha_{0}+\alpha_{1} \log \left(y_{t}\right)
$$

where the parameters $\alpha_{0}$ and $\alpha_{1}$ give the flexibility to match the levels of debt and spreads in the data (Chatterjee and Eyigungor (2012)).

\footnotetext{
${ }^{1}$ Sovereign debt contracts often contain an acceleration clause and a cross-default clause. The first clause allows creditors to call the debt they hold in case the government defaults on a debt payment. The cross-default clause states that a default in any government obligation constitutes a default in the contract containing that clause. These clauses imply that after a default event, future debt obligations become current (Bianchi et al. (2018)).
} 
The debt is given by the following dynamics:

$$
b_{t+1}=(1-\delta) b_{t}+i_{t},
$$

where $b_{t}$ represents the bonds due at the beginning of period $t$ and $i_{t}$ is the amount of bonds issued in period $t$. We assume that a bond issued in period $t$ promises to pay a deterministic infinite stream of coupons, which decreases at an exogenous constant rate, $\delta$. It means that a bond issued in period $t$ pays $\delta(1-\delta)^{j-1}$ units of the tradable good in period $t+j$, for all $j \geq 1$.

To capture exogenous disruptions in the international credit markets, we introduce a global shock that increases the foreign lenders' risk aversion. Aguiar et al. (2016) show that sovereign defaults are not tightly connected to poor fundamentals and that risk premia are an important component of sovereign spreads. Arellano (2008) document that default risk premium can be the additional component in the spread of defaultable bonds. We, then, use the stochastic discount factor of foreign lenders to price default risks and debt because debt bonds in our model are held by foreign creditors, which means that it is their risk aversion that most matters in this case. If defaults occur when the lender's stochastic discount factor is high, defaultable loans will carry a premium higher than the probability of default.

Then, following Bianchi et al. (2018), we define the discount factor of foreign lenders as:

$$
m_{t, t+1}^{f}=e^{-r-\left(\kappa_{t} \epsilon_{t+1}+0.5 \kappa_{t}^{2} \sigma_{\epsilon}^{2}\right)},
$$

where $r$ is the discount rate and $\kappa_{t} \geq 0$ is the parameter governing the riskpremium shock, which follows a two-state Markov process with transition probabilities $\pi_{L H}$ and $\pi_{H L}$. In normal times, $\kappa_{t}=\kappa_{L}=0$, lenders are risk neutral. When $\kappa_{t}=\kappa_{H}>0$, lenders are risk averse and require a higher expected return to buy government bonds. This formulation of the stochastic discount factor $m_{t, t+1}^{f}$ introduces a positive risk premium because bond payoffs are more valuable to lenders in states in which the government defaults when income shocks $\epsilon$ are low. Then, it generates a time-varying endogenous risk premium on sovereign bonds that captures disturbances to international financial markets that are exogenous to local conditions.

\section{1}

\section{Recursive Government Problem}

Following Epstein and Zin (1989) and Weil (1989), we introduce recursive preferences given by:

$$
V_{t}=\left[(1-\beta) c_{t}^{1-1 / \eta}+\beta\left[\mathbb{E}_{t}\left(V_{t+1}^{1-\sigma}\right)\right]^{\frac{1-1 / \eta}{1-\sigma}}\right]^{\frac{1}{1-1 / \eta}},
$$


where $\sigma$ is the relative risk aversion, $\eta$ is the elasticity of intertemporal substitution and $\beta$ denotes the discount factor. When $\sigma=\frac{1}{\eta}$, the time-additive expected utility specification emerges, i.e., formulation (2-5) reduces to CRRA preferences.

Let $V^{R}(a, b, s)$ denote the value function of the government when it repays its debt, which is given by:

$$
\begin{aligned}
& V^{R}(a, b, s)=\max _{a^{\prime} \geq 0, b^{\prime} \geq 0}\left\{\left[(1-\beta) c^{1-1 / \eta}+\beta\left[\mathbb{E}_{s^{\prime} \mid s}\left(V\left(b^{\prime}, a^{\prime}, s^{\prime}\right)^{1-\sigma}\right)\right]^{\frac{1-1 / \eta}{1-\sigma}}\right]^{\frac{1}{1-1 / \eta}}\right\}, \\
& \text { s.t. } \quad c=y+a+q\left(b^{\prime}, a^{\prime}, s\right)\left[b^{\prime}-(1-\delta) b\right]-\delta b-q_{a} a^{\prime}-g .
\end{aligned}
$$

The government finances consumption $c$, a fixed government expenditure $g$, coupon payments $\delta b$ and reserve accumulation $q_{a} a^{\prime}$ with income $y$, the initial stock of reserves $a$ and by issuing new debt $q i$, in which $i$ is given by the debt dynamics in (2-3).

Now, let $V^{D}(a, s)$ denote the value function of the government upon default, which is as follows:

$$
\begin{aligned}
& V^{D}(a, s)=\max _{a^{\prime} \geq 0}\left\{\left[(1-\beta) c^{1-1 / \eta}+\beta\left[\mathbb{E}_{s^{\prime} \mid s}\left(V\left(0, a^{\prime}, s^{\prime}\right)^{1-\sigma}\right)\right]^{\frac{1-1 / \eta}{1-\sigma}}\right]^{\frac{1}{1-1 / \eta}}-U^{D}(y)\right\}, \\
& \text { s.t. } \quad c=y+a-q_{a} a^{\prime}-g .
\end{aligned}
$$

Upon default, the government retains control only of its reserves and access to savings, since the economy is excluded from debt markets for one period. The consumption, new reserve assets and the fixed government spending are financed by the income and the previous stock of reserves.

Hence, the value function of the government satisfies the following condition:

$$
V(a, b, s)=\max \left\{V^{R}(a, b, s), V^{D}(a, s)\right\} .
$$

The solution to the government's problem yields decision rules for debt $\hat{b}(a, b, s)$, reserves upon repayment $\hat{a}^{R}(a, b, s)$ and upon default $\hat{a}^{D}(a, s)$, consumption upon repayment $\hat{c}^{R}(a, b, s)$ and upon default $\hat{c}^{D}(a, s)$. It also delivers an optimal default decision $\hat{d}(a, b, s)$, which is equal to 1 if the government defaults and 0 otherwise.

Then, the equilibrium bond price function is given by:

$$
q\left(a^{\prime}, b^{\prime}, s\right)=\mathbb{E}_{s^{\prime} \mid s}\left\{m^{f}\left(s^{\prime}, s\right)\left[1-\hat{d}\left(a^{\prime}, b^{\prime}, s^{\prime}\right)\right]\left[\delta+(1-\delta) q\left(a^{\prime \prime}, b^{\prime \prime}, s^{\prime}\right)\right]\right\},
$$

where $b^{\prime \prime}=\hat{b}\left(a^{\prime}, b^{\prime}, s^{\prime}\right)$ and $a^{\prime \prime}=\hat{a}^{R}\left(a^{\prime}, b^{\prime}, s^{\prime}\right)$. It shows that bond prices depend not only on the debt issued but also on the new stock of reserves. Using the stochastic discount factor of the foreign lenders, the price of the risk-free assets, which are the international reserves, is given by:

$$
q_{a}=e^{-r}
$$




\section{2}

\section{Recursive Equilibrium}

A Markov perfect equilibrium for this economy is defined by

1. a set of value functions $V, V^{R}$, and $V^{D}$,

2. rules for default $\hat{d}$, borrowing $\hat{b}$, reserves $\left\{\hat{a}^{R}, \hat{a}^{D}\right\}$, and consumption $\left\{\hat{c}^{R}, \hat{c}^{D}\right\}$,

3. and a bond price function $q$

such that

- given a bond price function $q$, the policy and the value functions solve the Bellman equations (2-6), (2-7), and (2-8);

- given government policies, the bond price function $q$ satisfies condition $(2-9)$.

\section{3}

\section{The Equity Premium}

The equity premium for this economy is computed using an asset pricing model following Lucas (1978), apart from the sovereign debt model with international reserves. The equilibrium generated by the sovereign default model is used in the asset pricing block in order to simulate the equity premium, which does not interfere in the decision rules of the government.

Despite the massive wave of financial globalization over the last decades and a much expanded world market for equities, international portfolios remain heavily tilted toward domestic assets. ${ }^{2}$ This is the equity home bias defined by French and Poterba (1991), Tesar and Werner (1995) and Ahearne et al. (2004). Coeurdacier and Gourinchas (2016) show that the domestic equity bias arise when the excess equity returns are positively correlated with a riskfactor that impacts negatively domestic investor's wealth relatively more than foreigner's. In this case, domestic equities become a good hedge against that risk factor. The explanations for the home bias range from nontraded factors and consumption goods (Baxter et al. (1998)) to asymmetries of information (Gehrig (1993)). Obstfeld and Rogoff (2001) focus on trade costs and Ahearne et al. (2004) study information costs as an indirect barrier affecting the investor's behavior toward domestic assets.

\footnotetext{
${ }^{2}$ As a share of GDP of industrialized countries, gross foreign equity and direct investment positions have been multiplied by more than four between 1983 and 2003. See Lane and Milesi-Ferretti (2003) and Coeurdacier and Gourinchas (2016).
} 
The puzzling preference for home assets suggest that we should use the domestic discount factor to price the equity claims in our model. The equity claims provide an expected return $\mathbb{E}_{t}\left(r_{t+1}^{e}\right)$, which includes a dividend stream $y_{t}$, and the bonds earn a risk-free real gross interest rate $r$. Using Epstein-Zin preferences and the outcomes from our sovereign debt model, the price of an equity claim $p$ depends on the state of the economy and the equilibrium rules for borrowing and reserves. The equilibrium equity price function is as follows:

$$
p(a, b, s)=\mathbb{E}_{s^{\prime} \mid s}\left\{m^{d}\left(a^{\prime}, b^{\prime}, s\right)\left[p\left(a^{\prime}, b^{\prime}, s^{\prime}\right)+y^{\prime}\right]\right\},
$$

where $m^{d}\left(a^{\prime}, b^{\prime}, s\right)$ denotes the stochastic discount factor of domestic agents, which is given by:

$$
m^{d}\left(a^{\prime}, b^{\prime}, s\right)=\beta\left(\frac{c^{\prime}}{c}\right)^{-\frac{1}{\eta}}\left[\frac{V\left(a^{\prime}, b^{\prime}, s^{\prime}\right)}{\left[\mathbb{E}_{s^{\prime} \mid s}\left(V\left(a^{\prime}, b^{\prime}, s^{\prime}\right)^{1-\sigma}\right)\right]^{\frac{1}{1-\sigma}}}\right]^{-\left(\sigma-\frac{1}{\eta}\right)},
$$

where $V$ is the government value function generated by the sovereign debt model.

Hence, the expected equity return $r^{e}$ is given by:

$$
\mathbb{E}_{s^{\prime} \mid s}\left(r^{e}\left(a^{\prime}, b^{\prime}, s\right)\right)=\frac{\mathbb{E}_{s^{\prime} \mid s}\left(p\left(a^{\prime}, b^{\prime}, s^{\prime}\right)+y^{\prime}\right)}{p(a, b, s)},
$$

while the return on the risk-free asset is defined as the risk-free rate $r$ in our model. Note that the expected differential of returns, $\mathbb{E}_{s^{\prime} \mid s}\left[r^{e}\left(a^{\prime}, b^{\prime}, s\right)-r\right]$, is the equity premium. ${ }^{3}$

Although the asset pricing theory is qualitatively correct in predicting a positive equity premium, it fails quantitatively because the equity premium observed in data tends to be much higher than the premium predicted by the model, often requiring an implausible level of the domestic risk aversion. ${ }^{4}$ This is the equity premium puzzle defined by Mehra and Prescott (1985), which demonstrate it in a general equilibrium model with CRRA preferences and show that it requires a risk aversion higher than 10 to generate the equity premium of $6.18 \%$ observed in U.S. from 1889 to 1978 . As pointed out by Kocherlakota (1996), stocks are not sufficiently riskier than bonds in the model to rationalize such a high spread. Using Epstein-Zin preferences, Weil (1989) finds that an equity premium of $5.7 \%$ requires a risk aversion of 45 and a

${ }^{3}$ In Chapter 4, we compute the equity premium for the empirical analysis consistently with the quantitative framework. The observed equity premium in the data is calculated as the average difference between stock returns and the risk-free rate return, denoted as the 3-month US Treasury rate. We use log-returns for both the empirical analysis and the model simulations.

${ }^{4}$ Kocherlakota (1996) summarizes that "a vast majority of economists believe that values of $[\sigma]$ above ten (or, for that matter, above five) imply highly implausible behavior on the part of individuals". 
elasticity of intertemporal substitution of 0.1 .

The distinction between the domestic households' willingness to substitute consumption over time and their risk aversion provided by the Epstein-Zin preferences allows the calibration of the latter parameter to match the equity premium without interfering in the consumption volatility relative to income, which is one of the targeted moments of our model. Then, using recursive preferences, we can analyze the pure effect of the risk aversion into both the level of international reserves and the equity premium. Besides that, although a high level for the risk-aversion parameter is still required to match the equity premium, this formulation solves the risk-free interest rate puzzle, since higher values of the risk aversion do not increase the risk-free rate return. ${ }^{5}$

Hence, given risk-averse agents and a strong desire for insurance implied by high levels of risk aversion, the equity premium puzzle suggests a connection with the international reserves puzzle. By pricing an equity claim within the model of sovereign debt, we can calibrate the model to match the equity premium and, then, analyze the effect of the risk aversion of domestic agents on the optimal international reserves holdings.

${ }^{5}$ High levels of risk aversion in CRRA preferences generate larger values for the risk-free rate, which is not consistent because it tends to be quantitatively small in the data. This is documented by Weil (1989) as the risk-free rate puzzle. 


\section{3}

\section{Quantitative Analysis}

In this chapter, we describe the computation, the calibration and the results of the model simulations for Mexico.

The recursive government problem is solved by value function iteration, following Hatchondo et al. (2010). ${ }^{1}$ They show that interpolation methods may be significantly more efficient than the discrete state space technique when solving for default models. Then, the value functions, $V^{R}(a, b, s)$ and $V^{D}(a, s)$, and the equilibrium bond price function $q\left(\hat{a}^{R}, \hat{b}, s\right)$ are approximated using linear interpolation over $y$ and cubic spline interpolation over debt and reserves. We use 40 grids for reserves and debt, and 30 grids for income. Expectations are computed using 50 quadrature points for the income shock.

\section{1}

\section{Calibration}

Following Bianchi et al. (2018), we use part of their calibration for the Mexican economy with data from 1993 to 2014. Mexico is a common reference for studies on emerging economies because its business cycle displays the same properties that are observed in other emerging economies. However, Mexico's level of international reserves is much lower than the average level observed in other 42 countries. The same is true for its equity premium.

A period in the model refers to a year. Table 3.1 presents the calibration for some parameters in the model. The first subset describes the external calibration, which consists of parameters that can be directly pinned down from the data. The risk-free rate and the domestic discount factor are calibrated at $4 \%$ and 0.92 , respectively, which are standard in quantitative business cycle and sovereign default studies.

The parameters that govern the endowment process are set to mimic the behavior of logged and linearly detrended GDP. The estimation of the AR(1) process for the cyclical component of GDP from 1980 to 2014 yields $\rho=0.66$ and $\sigma_{\epsilon}=0.034$. The level of government consumption to GDP, $g$, is set at $12 \%{ }^{2}$ The coupon decaying rate, $\delta$, is set to match the average duration

\footnotetext{
${ }^{1}$ We use a criteria of convergence of $10^{-6}$.
}

${ }^{2}$ See Bianchi et al. (2018). 
of public debt in Mexico, which is 3 years. The second subset of Table 3.1 describes the internal calibration, which consists of parameters that are set to match a specific targeted moment in the data.

The Markov process of the risk-premium shock to foreign lenders is parameterized as in Bianchi et al. (2018). A period with high lenders' risk aversion is one in which the global EMBI+, excluding countries in default, is one standard deviation above the median over the sample period. ${ }^{3}$ Then, we have three episodes of a high risk premium every 20 years with an average of 1.25 years each, which implies that the transition probabilities are $\pi_{L H}=0.15$ and $\pi_{H L}=0.8$. These episodes are the Mexican crisis, from 1994 to 1995, the Russian default, in 1998, and the global financial crisis, in 2008. On average, the global EMBI+ was 2 percentage points higher in those periods than in normal times.

Table 3.1: Calibration

\begin{tabular}{clc}
\hline \hline Parameter & Description & Mexico \\
\hline \multicolumn{3}{c}{ External Calibration } \\
$\beta$ & Risk-free rate & 0.04 \\
$\rho$ & Domestic discount factor & 0.92 \\
$\sigma_{\epsilon}$ & Autocorrelation of $y$ & 0.66 \\
$g$ & Std. dev. of innovation to $y$ & 0.03 \\
$\delta$ & Government Consumption & 0.12 \\
$\pi_{L H}$ & Coupon decaying rate & 0.28 \\
$\pi_{H L}$ & Probability of transiting to high risk-premium & 0.15 \\
& Probability of transiting to low risk-premium & 0.80 \\
\hline$\eta$ & $\quad$ Internal Calibration \\
$\alpha_{0}$ & Elasticity of intertemporal substitution & 0.33 \\
$\alpha_{1}$ & Default cost & 13.15 \\
$\kappa_{H}$ & Pricing kernel & 87.00 \\
$\sigma$ & Risk aversion & 30.50 \\
\hline
\end{tabular}

The parameters of utility cost of defaulting $\left\{\alpha_{0}, \alpha_{1}\right\}$, the risk-premium shock parameter $\kappa_{H}$, the elasticity of intertemporal substitution $\eta$ and the coefficient of relative risk aversion $\sigma$ are calibrated to match the public debt-toincome ratio, the mean level of spreads, the average increase in spreads during high risk-premium periods, the volatility of consumption relative to output and the equity premium. The targeted moments of Mexico for the average debt and spreads are computed from 1993 to 2014, since we use the calibration from this

${ }^{3}$ They use quarterly data from 1993 to 2014. 
period, as available by Bianchi et al. (2018). However, since the MSCI returns with dividends are not available for this period, the equity premium target is calculated from 2000 to 2018, as in the empirical analysis. We compare our model simulations for reserves also using the more recent period from 2000 to 2018 , since the moment targets are very similar with the sample period used by Bianchi et al. (2018). ${ }^{4}$ The observed reserves in the recent period is $11.4 \%$, while it was $9.2 \%$ from 1993 to 2014 . The following table describes the targeted moments for the country.

Table 3.2: Targeted Moments, in \%

\begin{tabular}{lc}
\hline \hline Debt-to-GDP & 43.0 \\
Mean spreads level & 2.4 \\
Increase in spreads & 2.0 \\
Volatility of consumption relative to output & 1.0 \\
Equity Premium & 4.9 \\
\hline
\end{tabular}

We consider all public debt to set the debt target, since domestically held sovereign debt is also subject to rollover and default risk. Besides that, using only external debt would underestimate the debt burden faced by the government. ${ }^{5}$ The debt level in the simulations are computed as the present value of future debt obligations discounted at the risk-free rate, i.e., $\frac{\delta}{1-(1-\delta) e^{-r}} b_{t}$.

The targets for spreads are computed using the EMBI+ data, available at the Global Economic Monitor, by the World Bank. The sovereign spread, $r_{t}^{s}$, is computed as the difference between the return $i_{b}$ of holding the bond to maturity when no default is declared and the risk-free rate $r$. The yield $i_{b}$ satisfies the following equation:

$$
q_{t}=\sum_{j=1}^{\infty} \delta(1-\delta)^{j-1} e^{-j i_{b}} .
$$

The equity premium is computed as the average difference between the log-returns of the MSCI and the risk-free rate, which is defined as the 3month U.S. Treasury rate, both in real terms discounting the American CPI. The equity return in the data includes leveraged assets, while equities in the models simulations are not leveraged. As explained in Barro (2006), leverage does not affect the overall market value of claims on next period's output, which is still given by the expression (2-11). Then, following Barro (2006), we

${ }^{4}$ From 2000 to 2018 , the debt ratio was $44 \%$, while spreads and the volatility of consumption relative to output did not change.

${ }^{5}$ The debt target includes domestic and external debt. See Bianchi et al. (2018). 
work with a leverage equity return to connect our model with data. The debtto-equity ratio for the Mexican stock market in the period of 2002 to 2018 is $94.5 \%$, which is computed using data from Bloomberg. ${ }^{6}$ Hence, we consider a leverage factor of 1.945 and calibrate the risk-aversion parameter to match the leveraged equity premium.

For the other moments, the values for the default cost coefficients mainly determine the average debt and spread levels, while $\kappa_{H}$ mainly determines the average increase in spreads in periods of high lenders' risk aversion. The calibration of the elasticity of intertemporal substitution affects mainly the consumption-volatility target.

The internal calibration of the default cost and the risk premium parameters are different for each value of the domestic risk aversion, in order to match the targeted moments. Table 3.3 describes the calibration relative to each risk-aversion parameter. We document the optimal level of international reserves and the equity premium while varying the risk aversion of the domestic agent in a comparative statics. Then, the parameters $\left\{\alpha_{0}, \alpha_{1}, \kappa_{H}, \eta\right\}$ are chosen to generate their respective targeted moments.

Table 3.3: Internal Calibration for the Comparative Statics

\begin{tabular}{clcccc}
\hline \hline Parameter & Description & \multicolumn{4}{c}{ Calibration } \\
\hline$\sigma$ & Risk aversion & 3.30 & 8.0 & 12.00 & 15.00 \\
\hline$\alpha_{0}$ & Default cost & 2.45 & 4.90 & 8.65 & 13.15 \\
$\alpha_{1}$ & Default cost & 19.00 & 38.00 & 63.00 & 87.00 \\
$\kappa_{H}$ & Pricing kernel & 23.00 & 23.50 & 26.00 & 30.50 \\
$\eta$ & Elasticity of intertemporal substitution & 0.30 & 0.33 & 0.33 & 0.33 \\
\hline
\end{tabular}

\section{2}

\section{Results}

Table 3.4 reports the long-run moments and the results generated by the model when targeting the equity premium for Mexico. Moments in the simulation are computed by generating 1,000 simulation samples of 300 periods each. We take the last 35 observations of samples in which the last default was observed at least 25 periods before the beginning of the sample in order to avoid dependency by initial conditions.

The simulations closely match the targeted moments for Mexico and generate a mean level of reserves to GDP consistent with the data. We set the risk-aversion parameter at 15.0 to match a real equity premium close to $4.9 \%$, which gives $12.7 \%$ of reserves relative to output. The results are in accordance

\footnotetext{
${ }^{6}$ The debt-to-equity ratio is also in accordance with the literature, since Pech et al. (2015) found a ratio of $92 \%$ using Mexican data from 1995 to 2011.
} 
with data, since the mean level of reserves from 2000 to 2018 for Mexico is $11.4 \%$.

Table 3.4: Results for Mexico, in $\%$

\begin{tabular}{lcc}
\hline \hline & Data & $\begin{array}{c}\text { Model } \\
\sigma=15.0\end{array}$ \\
\hline Targeted & & \\
Debt-to-income & 43.0 & 43.2 \\
Mean Spread & 2.4 & 2.0 \\
Increase in Spread & 2.0 & 2.2 \\
SD(c)/SD(y) & 1.0 & 1.0 \\
Equity Premium & 4.9 & 4.8 \\
\hline Nontargeted & & \\
Reserves-to-income & 11.4 & 12.7 \\
SD(Equity Premium) & 27.0 & 18.0 \\
\hline
\end{tabular}

\subsection{1}

\section{Comparative Statics}

Now we study the sensitivity of our results to the risk-aversion parameter. We show that a higher level of risk aversion increases both the level of reserves chosen by the government and the equity premium in the economy, revealing a clear connection between the puzzles. Table 3.5 displays the comparative statics for Mexico when varying the domestic risk-aversion parameter in model simulations. ${ }^{7}$

${ }^{7}$ We use the same targeted moments and calibration for Mexico in this comparative statics. 
Table 3.5: Comparative Statics for Mexico, in \%

Risk Aversion

$\begin{array}{llll}3.3 & 8.0 & 12.0 & 15.0\end{array}$

\begin{tabular}{lcccc}
\hline Targeted & & & & \\
Debt-to-income & 43.4 & 43.4 & 43.4 & 43.2 \\
Spread & 2.4 & 2.4 & 2.2 & 2.0 \\
Increase in Spread & 2.0 & 2.0 & 2.1 & 2.2 \\
sd(c)/sd(y) & 1.0 & 1.0 & 1.0 & 1.0 \\
\hline Nontargeted & & & & \\
Reserves-to-income & 6.0 & 8.6 & 11.3 & 12.7 \\
Equity Premium & 0.2 & 3.6 & 4.4 & 4.8 \\
$\quad$ Equity Return & 4.4 & 6.2 & 6.6 & 6.8 \\
$\quad$ Standard Deviation & 14.6 & 16.3 & 17.3 & 18.0 \\
\hline
\end{tabular}

Model simulations confirm that a country with a higher equity premium tends to accumulate more international reserves than a country that presents a lower premium. Note that increasing the risk aversion of the domestic agents from 3.3 to 15.0 the level of reserves-to-income more than doubles, increasing 6.7 percentage points, while the equity premium increases from $0.3 \%$ to $4.8 \%$. In particular, higher levels of risk aversion make the government more reluctant to tolerate sharp drops in consumption and low levels of income shocks, increasing the desire to save and accumulate international reserves as a hedge against financial crises.

Then, we have a robust result in which risk aversion is quantitatively important to generate both the equity premium and the international reserves in this economy, revealing a strong connection between the puzzles. This pattern is clear when we do not target the equity premium, as in the comparative statics, and let it vary with the risk aversion parameter. Figure 3.1 shows how reserves increase with the equity premium and the risk aversion, and how our model simulations fit the data for Mexico. 


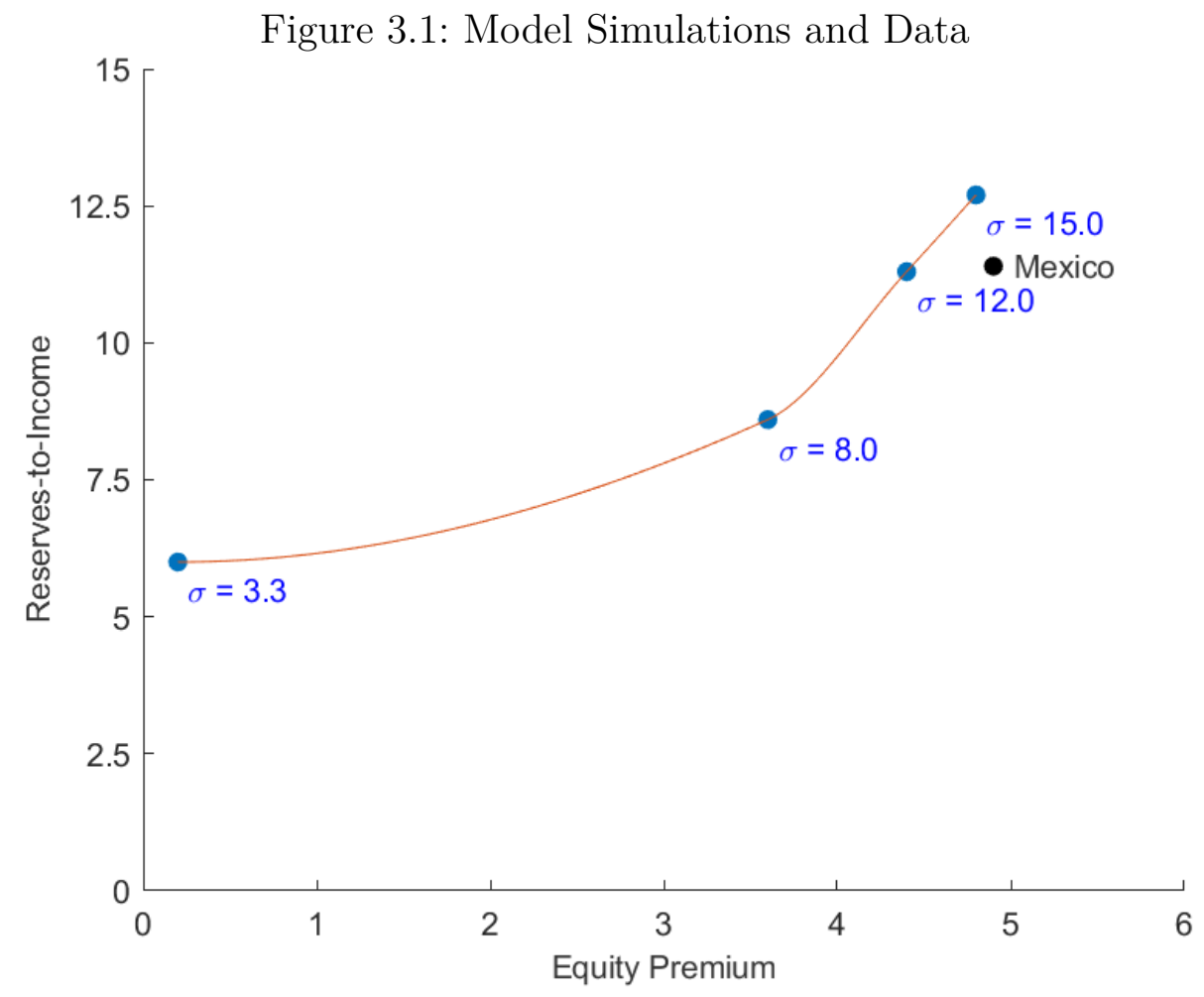

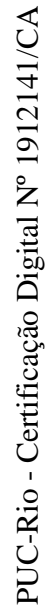




\section{4}

\section{Empirical Evidence}

This chapter presents empirical evidence regarding the relationship between international reserves and equity premium. Section 4.1 describes the data sources used, section 4.2 provides the results from panel regressions and the last section documents that the results hold in a pure cross section. To foreshadow our main conclusion, we find that countries with a higher equity premium tend to accumulate more reserves, which is consistent with our quantitative results. In Section C of the Appendix, we also display the empirical results using a restricted sample excluding the outliers ${ }^{1}$ and show that the results remain robust.

\section{1 \\ Data}

Unless specified otherwise, we use annual data from 2000 to $2018^{2}$ for a set of 42 countries, including developed and emerging economies. ${ }^{3}$ For reserves, we consider the Official Reserve Assets in US dollar from the International Financial Statistics (IFS), published by the International Monetary Fund (IMF). The GDP data is retrieved from the World Economic Outlook Database, also from IMF.

The data used to compute the equity premium consist of the Morgan Stanley Capital International (MSCI) Value Gross Index in US dollar for each country, which includes dividends earnings, and the 3-month US Treasury rate. $^{4}$ The equity premium is the difference between the annual average logreturns of MSCI and the annual average risk-free rate, both discounting the American inflation.

${ }^{1}$ As mentioned in the Introduction, the outliers are Greece, Hong Kong, Ireland, Singapore and Switzerland.

${ }^{2}$ Since several emerging economies experienced a high uncertainty (Brazil, for example, faced a hyperinflation period in the 1980's) and financial crises (Mexican crisis in 1995 and Asian crisis in 1998) in the period before 2000, we set the start of our sample at 2000.

${ }^{3}$ The countries used in our sample are Australia, Austria, Belgium, Brazil, Canada, Chile, Hong Kong, China, Colombia, Czech Republic, Denmark, Egypt, Finland, France, Germany, Greece, Hungary, India, Ireland, Israel, Italy, Japan, Korea, Malaysia, Mexico, Netherlands, New Zealand, Norway, Peru, Philippines, Poland, Portugal, Russia, Singapore, South Africa, Spain, Sweden, Switzerland, Thailand, Turkey, United Kingdom and United States.

${ }^{4}$ The 3-month US Treasury rate is retrived from the Federal Reserve Bank of St. Louis (FRED) database. 
Following Obstfeld et al. (2010) and Samano (2020) for our canonical model of estimation, we also consider data for public debt, openness degree, monetary aggregate M2 and exchange rate regime. In our sample, public debt includes debt denominated in domestic and foreign currency, and issued domestically or externally. The openness degree is measured by the ratio of foreign trade (imports plus exports) to GDP. Both series are retrieved from the IMF. The money supply, M2, is retrieved from national sources and it consists of 38 countries. ${ }^{5}$

Following the fine classification codes from Ilzetzki et al. (2019), we define the exchange rate regime for each country as a dummy variable, which assigns 0 to flexible and 1 to fixed exchange rates. Given the data availability, the sample period for this variable is from 2000 to 2016 .

Table 4.1 presents some summary statistics for the entire sample of 42 countries from 2000 to 2018.

\begin{tabular}{lcc}
\multicolumn{3}{c}{ Table 4.1: Summary Statistics, in \% } \\
\hline \hline & Mean & Median \\
\hline Reserves-to-GDP & 18.9 & 11.8 \\
Equity Premium & 3.8 & 5.0 \\
Debt-to-GDP & 61.2 & 57.0 \\
Openness Degree & 88.4 & 66.9 \\
\hline
\end{tabular}

\section{2}

\section{Panel Regressions}

In order to study the empirical relationship between international reserves and equity premium, we estimate panel regressions controlling for other confounding factors, as the ratio of debt to GDP, the openness degree, the ratio of M2 to GDP and the exchange rate regime. ${ }^{6}$ We take the average of the excess returns in windows of 6 years in our sample, resulting in a panel composed by 3 periods. ${ }^{7}$ The following regression summarizes the panel estimation using pooled OLS:

${ }^{5}$ There is no such data available for Australia, Belgium, Israel and New Zealand.

${ }^{6}$ In previous estimations, we also controlled for the level of spreads using the Credit Default Swap (CDS) for each country, but its coefficient was not statistically significant. Besides that, CDS data is only available since 2007, which considerably reduces the time period of our sample. Then, we excluded the CDS from the control variables in the regressions.

${ }^{7}$ We originally had annual data from 2000 to 2018. Taking the average of our data in windows of 6 years each, we remain with 3 periods, in which the last one is composed by averages of the remaining 7 years. The annual data informs only the difference of returns in our sample, then we need to take the averages over time to account for the equity premium. 


$$
(R e s)_{i, t}=\beta_{1}(E P)_{i, t}+\beta_{2}^{\prime}(X)_{i, t}+\epsilon_{i, t}
$$

where $R e s_{i, t}$ is the ratio reserves-to-GDP of country $i$ in period $t, E P_{i, t}$ is the equity premium, $X_{i, t}$ represents the control variables and $\epsilon_{i, t}$ denotes the regression residuals. As computed for the equity premium, we also take the average for all the other variables over the windows periods. The intensity of the exchange rate regime in each country goes from 0 to 1 , in which a measure closer to 1 means that the country experienced a fixed exchange rate for a longer time.

Table 4.2 reports the results for the panel regressions. The main finding is that, other things equal, countries with a higher equity premium tend to accumulate more reserves, which is robust to several controls and specifications. In specification (6), for example, an increase of 1 percentage point (p.p.) in a country's $i$ equity premium is associated with a 0.31 p.p. increase in reserve holdings.

Note that the regressions show the conditional correlations between reserves and equity premium, controlling by the confounding factors. Since we keep the targeted moments fixed in the model simulations, this is consistent with our quantitative analysis. Then, the regressions contemplate usual controls in the literature, with the exception of the first specification. The unconditional correlation found in specification (1) is in line with the conditional correlations and corroborates the robustness of our results, since the coefficients are very similar in all specifications.

The effect of the control factors on the reserve accumulation is in accordance with the literature. Economies that trade more, i.e., that present a higher openness degree, tend to hold more reserves, which is also found by Obstfeld et al. (2010) and Aizenman and Lee (2007). Although debt is not statistically significant in this specification, it tends to slightly reduce the level of reserves, since it represents a cost in accumulating international reserves. This result goes in line with Rodrik (2006), Bianchi et al. (2018) and Samano (2020).

As expected, the money supply ratio M2-to-GDP has a positive influence over reserves. We also find that countries with a fixed exchange rate regime tend to accumulate more reserves, which is consistent with previous studies such as Obstfeld et al. (2010), Bianchi and Sosa-Padilla (2020) and Samano (2020). 
Table 4.2: Panel Pooled OLS Regressions, 3 windows

\begin{tabular}{lcccccc}
\hline \hline & & \multicolumn{5}{c}{ Dependent variable: Reserve-to-GDP } \\
& $(1)$ & $(2)$ & $(3)$ & $(4)$ & $(5)$ & $(6)$ \\
\hline Equity Premium & $0.289^{* * *}$ & $0.334^{* * *}$ & $0.291^{* *}$ & $0.368^{* * *}$ & $0.237^{* *}$ & $0.310^{* * *}$ \\
& $(0.097)$ & $(0.103)$ & $(0.119)$ & $(0.103)$ & $(0.114)$ & $(0.097)$ \\
Openness & & $0.217^{* * *}$ & $0.214^{* * *}$ & $0.168^{* * *}$ & $0.222^{* * *}$ & $0.169^{* * *}$ \\
& & $(0.021)$ & $(0.021)$ & $(0.029)$ & $(0.019)$ & $(0.025)$ \\
Debt-to-GDP & & & -0.043 & -0.040 & -0.034 & -0.038 \\
& & & $(0.043)$ & $(0.033)$ & $(0.039)$ & $(0.028)$ \\
M2-to-GDP & & & & $0.100^{* * *}$ & & $0.109^{* * *}$ \\
& & & & $(0.025)$ & & $(0.023)$ \\
FX Regime & & & & & $0.071^{* * *}$ & $0.077^{* * *}$ \\
& & & & & $(0.022)$ & $(0.020)$ \\
Constant & $0.170^{* * *}$ & -0.027 & 0.003 & -0.036 & -0.045 & $-0.081^{* *}$ \\
& $(0.017)$ & $(0.018)$ & $(0.033)$ & $(0.031)$ & $(0.036)$ & $(0.033)$ \\
\hline Observations & 126 & 126 & 126 & 113 & 126 & 113 \\
Number of countries & 42 & 42 & 42 & 38 & 42 & 38 \\
$\mathrm{R}^{2}$ & 0.020 & 0.594 & 0.599 & 0.688 & 0.624 & 0.716 \\
Adjusted $\mathrm{R}^{2}$ & 0.013 & 0.587 & 0.589 & 0.676 & 0.612 & 0.703 \\
F Statistic & 2.595 & $89.795^{* * *}$ & $60.730^{* * *}$ & $59.531^{* * *}$ & $50.270^{* * *}$ & $53.915^{* * *}$ \\
\hline \hline
\end{tabular}

Note: Robust standard errors are reported in parentheses. ${ }^{*} \mathrm{p}<0.1 ;{ }^{* *} \mathrm{p}<0.05 ;{ }^{* * *} \mathrm{p}<0.01$.

In Section B of the Appendix, we display the results for the panel regressions with annual data and with 2 windows of, roughly, 9 years each. The panel with annual data is estimated by controlling for country and time fixed effects. The panel regressions of 2 windows are estimated by both methods, pooled OLS and fixed effects of country and time. The results are consistent with the estimations of Table 4.2, since the equity premium has a positive association with the level of reserves in all panel regressions, including fixed effects or not.

\section{3}

Pure Cross-Section Regressions

Now, we estimate a pooled OLS regression on a pure cross-section with the same 42 countries used in the previous section. The panel consists of historical averages from 2000 to 2018 for reserve-to-GDP ratio, debt-to-GDP, openness degree, M2-to-GDP ratio and exchange rate regime. The following regression summarizes the cross-section estimation:

$$
(\overline{R e s})_{i}=\beta_{1}(\overline{E P})_{i}+\beta_{2}^{\prime}(\bar{X})_{i}+v_{i}
$$

where $\overline{R e s}_{i}$ is the average ratio reserves-to-GDP of country $i, \overline{E P}_{i}$ is the average equity premium, $\bar{X}_{i}$ represents the average of the control variables and $v_{i}$ denotes the regression residuals.

Table 4.3 reports the results for the cross-country regressions. Economies that trade more hold more reserves, and the money supply ratio M2-to- 
GDP and the fixed exchange rate regime have a positive coefficient in the specifications. Since it is necessary to issue debt to accumulate more reserves, the effect of the levels of debt is ambiguous in the literature. Although the debt-to-GDP ratio is not significant in our cross-section regressions, it has a slightly positive relation with reserves, which is consistent with Bianchi and Sosa-Padilla (2020) findings.

As in the previous estimations, a higher equity premium tends to present a positive relation with the accumulation of international reserves and this finding is robust to several controls and specifications, in which the coefficients of the equity premium do not vary much. It means that our results are robust and hold in a pure cross section, then serial correlation is not driving the results or generating spurious-regression effects.

Table 4.3: Pure Cross-Section Regressions

\begin{tabular}{lcccccc}
\hline \hline & \multicolumn{5}{c}{ Dependent variable: Reserve-to-GDP } \\
& $(1)$ & $(2)$ & $(3)$ & $(4)$ & $(5)$ & $(6)$ \\
\hline Equity Premium & $1.026^{* * *}$ & $1.125^{* *}$ & $1.175^{* *}$ & $1.375^{* * *}$ & $1.083^{* *}$ & $1.149^{* *}$ \\
& $(0.264)$ & $(0.418)$ & $(0.487)$ & $(0.429)$ & $(0.504)$ & $(0.429)$ \\
Openness & & $0.219^{* * *}$ & $0.220^{* * *}$ & $0.166^{* * *}$ & $0.231^{* * *}$ & $0.165^{* * *}$ \\
& & $(0.030)$ & $(0.029)$ & $(0.034)$ & $(0.028)$ & $(0.029)$ \\
Debt-to-GDP & & & 0.015 & 0.022 & 0.021 & 0.012 \\
& & $(0.070)$ & $(0.044)$ & $(0.058)$ & $(0.038)$ \\
M2-to-GDP & & & $0.115^{* * *}$ & & $0.124^{* * *}$ \\
& & & & $(0.026)$ & & $(0.027)$ \\
FX Regime & & & & & 0.058 & $0.078^{* *}$ \\
& & & & & & \\
Constant & $0.150^{* * *}$ & -0.052 & -0.064 & $-0.115^{* *}$ & $-0.097^{*}$ & $-0.146^{* * *}$ \\
& $(0.028)$ & $(0.034)$ & $(0.058)$ & $(0.052)$ & $(0.057)$ & $(0.047)$ \\
\hline Observations & 42 & 42 & 42 & 38 & 42 & 38 \\
$\mathrm{R}^{2}$ & 0.075 & 0.658 & 0.658 & 0.769 & 0.718 & 0.792 \\
Adjusted ${ }^{2}$ & 0.052 & 0.640 & 0.631 & 0.742 & 0.684 & 0.759 \\
F Statistic & $3.246^{*}$ & $37.436^{* * *}$ & $24.369^{* * *}$ & $27.536^{* * *}$ & $20.996^{* * *}$ & $24.347^{* * *}$ \\
\hline \hline
\end{tabular}

Note that in specification (6) of the pure cross-section regression, an increase of 1 p.p. in a country's $i$ equity premium is associated with a 1.15 p.p. increase in reserve holding. This result is much stronger than the previous regressions from the panel in 3 windows, in which the equity premium had a coefficient of 0.31 in the canonical specification. Then, it suggests that the relationship between equity premium and international reserves is even more robust and stronger when using data with longer averages, which is corroborated by a higher R-squared in the estimations.

Although our quantitative model is not linear, the observations around the comparative statics for Mexico in Chapter 3 suggest a local slope of 1.32 , which means that a 1 p.p. increase in equity premium is associated 
with an increase of 1.32 p.p. in reserves-to-GDP. ${ }^{8}$ Note that the coefficient suggested by the simulations is very similar to the estimated coefficients in the pure cross-section regressions, which are around 1.03 and 1.38 depending on the specification. It suggests that our results from the quantitative sovereign default model are in line with our empirical results, which corroborates and reinforces the evidence that a country with a higher equity premium tends to accumulate more international reserves. 


\section{5 \\ Conclusion}

This dissertation studies the quantitative and the empirical connection between international reserves and equity premium. In the quantitative analysis, we simulate a sovereign default model with international reserves and long-term debt in an incomplete markets framework with Epstein-Zin preferences, disciplining by the equity premium. We simulate the model for Mexican economy and show that model simulations can closely match the targeted moments and generate a consistent level of reserves-to-income for the country. The comparative statics for Mexico confirm the quantitative importance of the equity premium and risk aversion in the choice of reserves. As we raise the risk aversion of domestic agents, both the reserves and the equity premium increase, revealing a clear and strong connection between the puzzles.

For the empirical analysis, we estimate panel and cross-country regressions, in which all specifications display a positive and significant correlation between reserves and equity premium. It means that countries with a higher equity premium tend to accumulate more reserves, which is robust to several controls and specifications.

Then, both the empirical and the quantitative analysis show that countries with a higher equity premium tend to hold more international reserves. Risk-averse agents tend to require a higher equity return to self-insure against risks, and to be more reluctant to tolerate sharp drops in consumption and low levels of income shocks, increasing the desire to save and accumulate international reserves as a hedge against financial crises. 


\section{Bibliography}

Aguiar, M. and Amador, M. (2014). Sovereign debt. Handbook of International Economics, 4:647-687.

Aguiar, M., Chatterjee, S., Cole, H., and Stangebye, Z. (2016). Quantitative models of sovereign debt crises. Handbook of Macroeconomics, 2:1697-1755.

Aguiar, M. and Gopinath, G. (2006). Defautable debt, interest rates and the current account. Journal of International Economics, 69 (1):64-83.

Ahearne, A., Griever, W., and Warnock, F. (2004). Information costs and home bias: An analysis of us holdings of foreign equities. Journal of International Economics, 62 (2):313-336.

Aizenman, J. and Lee, J. (2007). International reserves: Precautionary versus mercantilist views, theory and evidence. Open Economics Review, 18 (2):191214.

Aizenman, J. and Marion, N. (2004). International reserve holdings with sovereign risk and costly tax collection. The Economic Journal, 114:569-591.

Alfaro, L. and Kanczuk, F. (2009). Optimal reserve management and sovereign debt. Journal of International Economics, 77 (1):23-36.

Alfaro, L. and Kanczuk, F. (2019). Debt redemption and reserve accumulation. IMF Economic Review, 67 (2):261-287.

Arellano, C. (2008). Default risk and income fluctuations in emerging economies. American Economic Review, 98 (3):690-712.

Arellano, C. (2014). Renegotiation policies in sovereign defaults. American Economic Review, 104 (5):94-100.

Arellano, C. and Ramanarayanan, A. (2012). Default and the maturity structure in sovereign bonds. Journal of Political Economy, 120 (2):187-232.

Barro, R. (2006). Rare disasters and asset markets in the twentieth century. The Quarter Journal of Economics, 121 (3):823-866. 
Baxter, M., Jermann, U., and King, R. (1998). Nontraded goods, nontraded factors, and international non-diversification. Journal of International Economics, 44 (2):211-229.

Benigno, G. and Fornaro, L. (2012). Reserve accumulation, growth and financial crises. Centre for Economic Performance, LSE, Discussion Paper dp1161.

Bianchi, J. (2011). Overborrowing and systemic externalities in the business cycle. American Economic Review, 101 (7):3400-3426.

Bianchi, J., Hatchondo, J., and Martinez, L. (2018). International reserves and rollover risk. American Economic Review, 108 (5):2629-2670.

Bianchi, J. and Sosa-Padilla, C. (2020). Reserve accumulation, macroeconomic stabilization, and sovereign risk. NBER Working Papers, 27323.

Calvo, G. A., Izquierdo, A., and Loo-Kung, R. (2012). Optimal holdings of international reserves: Self-insurance against sudden stop. NBER Working Paper, 18219.

Chatterjee, S. and Eyigungor, B. (2012). Maturity, indebtedness, and default risk. American Economic Review, 102 (6):2674-2699.

Chinn, M. D. and Ito, H. (2006). What matters for financial development? capital controls, institutions, and interactions. Journal of Development Economics, 81 (1):163-192.

Cochrane, J. (2017). Macro-finance. Review of Finance, 21 (3):945-985.

Coeurdacier, N. and Gourinchas, P. (2016). When bonds matter: Home bias in goods and assets. Journal of Monetary Economics, 82 (C):119-137.

Dominguez, K., Hashimoto, Y., and Ito, T. (2012). International reserves and the global financial crisis. Journal of International Economics, 88 (2):388-406.

Edwards, S. (2007). Capital controls, sudden stops and current account reversals. NBER Chapters, pages 73-120.

Epstein, L. and Zin, S. (1989). Substitution, risk aversion, and the temporal behavior of consumption and asset returns: A theoretical framework. Econometrica, 57 (4):937-969.

Fama, E. and French, K. (2002). The equity premium. The Journal of Finance, 57 (2):637-659. 
Feldstein, M. (1999). A self-help guide for emerging markets. Foreign Affairs, 78 (2):93-109.

French, K. and Poterba, J. (1991). Investor diversification and international equity markets. American Economic Review, 81 (2):222-226.

Frenkel, J. and Jovanovic, B. (1981). Optimal international reserves: A stochastic framework. The Economic Journal, 91 (362):507-514.

Gehrig, T. (1993). An information based explanation of the domestic bias in international equity investment. Scandinavian Journal of Economics, 95 (1):97109.

Hansen, L. and Singleton, K. (1983). Stochastic consumption, risk aversion, and the temporal behavior of asset returns. Journal of Political Economy, 91 (2):249265.

Hatchondo, J., Martinez, L., and Sapriza, H. (2010). Quantitative properties of sovereign default models: Solution methods matter. Review of Economic Dynamics, 13 (4):919-933.

Hatchondo, J. C. and Martinez, L. (2009). Long-duration bonds and sovereign defaults. Journal of International Economics, 79 (1):117-125.

Heller, H. (1966). Optimal international reserves. The Economic Journal, 76 (302):296-311.

Ilzetzki, E., Reinhart, C., and Rogoff, K. (2019). Exchange arrangements entering the 21st century: Which anchor will hold? Quarterly Journal of Economics, 134 (2):599-646.

Jeanne, O. (2007). International reserves in emerging market countries: Too much of a good thing? Brookings Papers on Economic Activity, 38 (1):1-80.

Jeanne, O. and Ranciere, R. (2011). The optimal level of international reserves for emerging market countries: a new formula and some applications. Economic Journal, 121 (555):905-930.

Kocherlakota, N. (1996). The equity premium: It's still a puzzle. Journal of Economic Literature, 34:43-71.

Korinek, A. and Simsek, A. (2016). Liquidity trap and excessive leverage. American Economic Review, 106 (3):699-738.

Lane, P. and Milesi-Ferretti, G. (2003). International financial integration. IMF Working Papers, 17 (115):82-113. 
Lewis, K. (1999). Trying to explain home bias in equities and consumption. Journal of Economic Literature, 37 (2):571-608.

Lewis, K. (2011). Global asset pricing. Globalization Institute Working Papers, Federal Reserve Bank of Dallas, 88.

Ljungqvist, L. and Sargent, T. (2012). Recursive Macroeconomic Theory. Massachusetts Institute of Technology, 2nd edition.

Lucas, R. (1978). Asset prices in an exchange economy. Econometrica, 46 (6):1429-1445.

Mehra, R. and Prescott, E. (1985). The equity premium: A puzzle. Journal of Monetary Economics, 15 (2):145-161.

Mendoza, E. (2010). Sudden stops, financial crises, and leverage. The American Economic Review, 100 (5):1941-1966.

Mendoza, E. and Smith, K. (2005). Quantitative implications of a debt-deflation theory of sudden stops and asset prices. Journal of International Economics, 70 (1):86-114.

Miao, J. (2013). Economic dynamics: Discrete time. Massachusetts Institute of Technology.

Obstfeld, M. and Rogoff, K. (2001). The six major puzzles in international macroeconomics: Is there a common cause? NBER Macroeconomics Annual 2000, pages 339-390.

Obstfeld, M., Shambaugh, J., and Taylor, A. (2010). Financial stability, the trilemma, and international reserves. American Economic Journal: Macroeconomics, 2 (2):57-94.

Pech, C., Noguera, M., and White, S. (2015). Financial ratios used by equity analysts in mexico and stock returns. Contaduría y Administración, 60:578-592.

Rodrik, D. (2006). The social cost of foreign exchange reserves. International Economic Journal, 20 (3):253-266.

Roettger, J. (2019a). Debt, default and commitment. University of Cologne, Center for Macroeconomic Research.

Roettger, J. (2019b). Debt, default, and commitment. University of Cologne.

Sabbadini, R. (2019). International reserves management in a model of partial sovereign default. Working Papers Series, Central Bank of Brazil, 496. 
Samano, A. (2020). International reserves and central bank independence. Job Market Paper, University of Minnesota.

Tesar, L. and Werner, I. (1995). Home bias and high turnover. Journal of International Money and Finance, 14 (4):467-492.

Tomz, M. and Wright, M. (2007). Do countries default in "bad times"? Journal of the European Economic Association, 5 (2/3):352-360.

Weil, P. (1989). The equity premium puzzle and the risk-free rate puzzle. Journal of Monetary Economics, 24 (3):401-421. 
A

\section{Cross-Section Data}

Table A.1: Cross-Section Data - Average from 2000 to 2018, in \%

\begin{tabular}{|c|c|c|c|}
\hline Country & Reserves-to-GDP & Equity Premium & $\begin{array}{l}\text { Standard Deviation } \\
\text { of Equity Premium }\end{array}$ \\
\hline Australia & 4.1 & 6.5 & 27.7 \\
\hline Austria & 5.3 & 3.3 & 46.3 \\
\hline Belgium & 4.7 & 0.0 & 38.3 \\
\hline Brazil & 14.1 & 6.1 & 49.8 \\
\hline Canada & 4.0 & 6.4 & 28.1 \\
\hline Chile & 14.9 & 6.2 & 31.0 \\
\hline China, P.R.: Hong Kong & 100.1 & 4.7 & 35.0 \\
\hline China, P.R.: Mainland & 34.0 & 7.8 & 33.5 \\
\hline Colombia & 11.8 & 13.7 & 42.3 \\
\hline Czech Rep. & 29.3 & 11.7 & 30.8 \\
\hline Denmark & 19.0 & 5.1 & 38.1 \\
\hline Egypt, Arab Rep. of & 11.7 & 2.6 & 43.8 \\
\hline Finland & 4.4 & -0.3 & 31.3 \\
\hline France & 5.0 & 2.3 & 26.4 \\
\hline Germany & 4.9 & 1.5 & 29.8 \\
\hline Greece & 2.6 & -18.5 & 58.4 \\
\hline Hungary & 24.5 & 6.5 & 36.0 \\
\hline India & 16.5 & 8.3 & 42.0 \\
\hline Ireland & 1.2 & -11.1 & 55.8 \\
\hline Israel & 26.3 & -0.4 & 30.7 \\
\hline Italy & 5.9 & 0.9 & 25.5 \\
\hline Japan & 20.0 & 1.0 & 19.8 \\
\hline Korea, Rep. of & 23.7 & 6.5 & 35.7 \\
\hline Malaysia & 38.1 & 5.8 & 22.0 \\
\hline Mexico & 11.4 & 4.9 & 27.0 \\
\hline Netherlands, The & 4.4 & 1.3 & 32.2 \\
\hline New Zealand & 9.4 & 9.6 & 29.8 \\
\hline Norway & 13.7 & 6.8 & 34.3 \\
\hline Peru & 28.0 & 11.5 & 42.2 \\
\hline Philippines & 25.1 & 3.0 & 35.2 \\
\hline Poland, Rep. of & 18.1 & 5.0 & 34.6 \\
\hline Portugal & 8.4 & -1.4 & 27.7 \\
\hline Russian Federation & 25.3 & 8.0 & 46.2 \\
\hline Singapore & 86.0 & 5.8 & 27.3 \\
\hline South Africa & 11.7 & 5.4 & 28.6 \\
\hline Spain & 3.2 & 2.2 & 29.6 \\
\hline Sweden & 8.9 & 6.8 & 31.1 \\
\hline Switzerland & 57.5 & 3.2 & 25.3 \\
\hline Thailand & 39.6 & 8.6 & 46.1 \\
\hline Turkey & 11.8 & -1.5 & 53.1 \\
\hline United Kingdom & 3.7 & 0.7 & 24.6 \\
\hline United States & 0.7 & 3.3 & 19.2 \\
\hline
\end{tabular}


B

\section{Panel Regressions}

Table B.1: Panel Fixed Effect Regressions with Annual Data

\begin{tabular}{|c|c|c|c|c|c|}
\hline & \multicolumn{5}{|c|}{ Dependent variable: Reserve-to-GDP } \\
\hline & (1) & $(2)$ & (3) & $(4)$ & $(5)$ \\
\hline \multirow[t]{2}{*}{ Equity Premium } & 0.012 & $0.029^{* *}$ & $0.027^{* *}$ & $0.037^{* * *}$ & $0.023^{* *}$ \\
\hline & $(0.015)$ & $(0.011)$ & $(0.011)$ & $(0.011)$ & $(0.011)$ \\
\hline \multirow[t]{2}{*}{ Openness } & & $0.201^{* * *}$ & $0.203^{* * *}$ & $0.159^{* * *}$ & $0.202^{* * *}$ \\
\hline & & $(0.008)$ & $(0.007)$ & $(0.010)$ & $(0.009)$ \\
\hline \multirow[t]{2}{*}{ Debt-to-GDP } & & & $-0.048^{* * *}$ & $-0.026^{* * *}$ & $-0.034^{* * *}$ \\
\hline & & & $(0.014)$ & $(0.014)$ & $(0.014)$ \\
\hline \multirow[t]{2}{*}{ GDP cycle } & & & $-0.061^{* * *}$ & -0.035 & $-0.042^{*}$ \\
\hline & & & $(0.023)$ & $(0.025)$ & $(0.023)$ \\
\hline \multirow[t]{2}{*}{ M2-to-GDP } & & & & $0.092^{* * *}$ & \\
\hline & & & & $(0.013)$ & \\
\hline \multirow[t]{2}{*}{ FX Regime } & & & & & $0.056^{* * *}$ \\
\hline & & & & & $(0.012)$ \\
\hline Country Fixed Effect & Yes & Yes & Yes & Yes & Yes \\
\hline Observations & 789 & 789 & 789 & 773 & 706 \\
\hline Number of countries & 42 & 42 & 42 & 38 & 42 \\
\hline $\mathrm{R}^{2}$ & 0.001 & 0.555 & 0.564 & 0.588 & 0.562 \\
\hline Adjusted $\mathrm{R}^{2}$ & -0.024 & 0.544 & 0.552 & 0.574 & 0.548 \\
\hline F Statistic & 0.450 & $479.871^{* * *}$ & $248.019^{* * *}$ & $192.768^{* * *}$ & $175.487^{* * *}$ \\
\hline
\end{tabular}

Note: All specifications include country and time fixed effects. Robust standard errors clustered by country are reported in parentheses. ${ }^{*} \mathrm{p}<0.1 ;{ }^{* *} \mathrm{p}<0.05 ;{ }^{* * *} \mathrm{p}<0.01$ 
Table B.2: Panel Fixed Effect Regressions with 2 windows

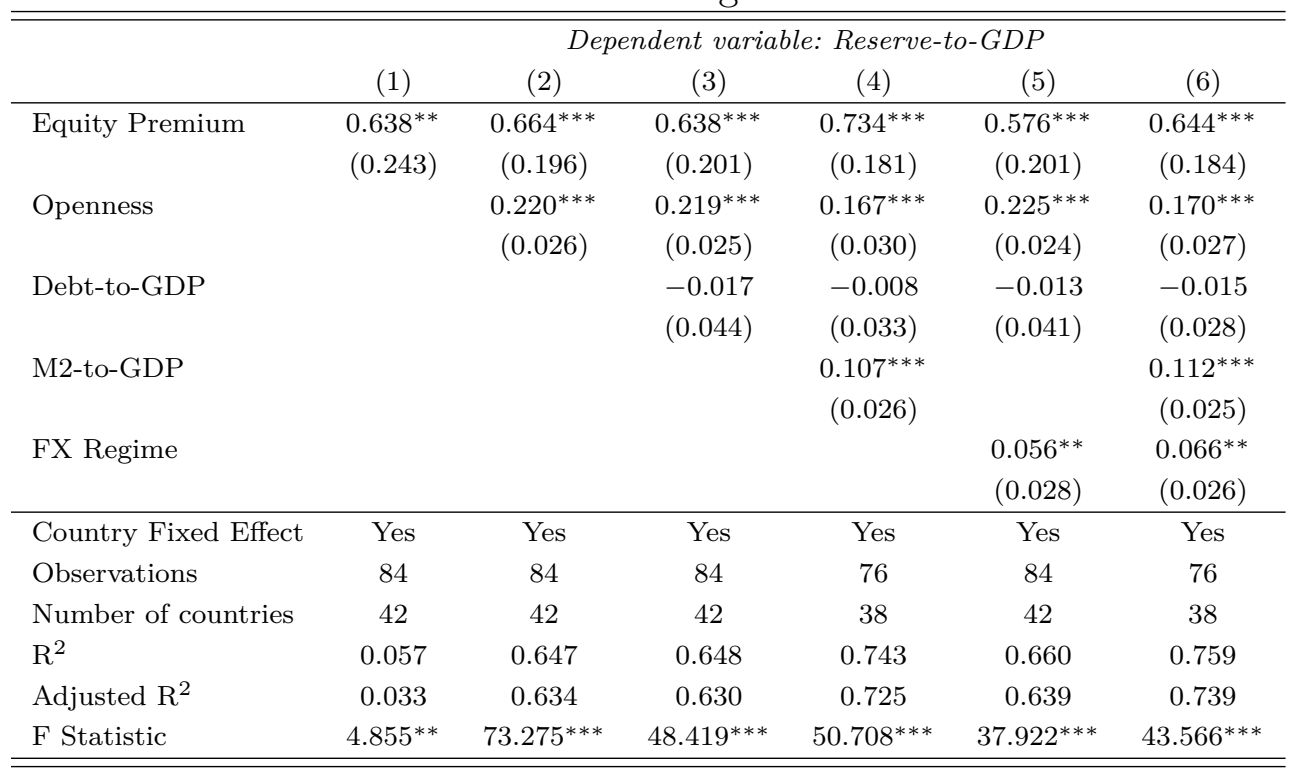

Note: All specifications include country and time fixed effects. Robust standard errors clustered by country are reported in parentheses. ${ }^{*} \mathrm{p}<0.1 ;{ }^{* *} \mathrm{p}<0.05 ;{ }^{* * *} \mathrm{p}<0.01$.

Table B.3: Panel Pooled OLS Regressions with 2 windows

\begin{tabular}{|c|c|c|c|c|c|c|}
\hline & \multicolumn{6}{|c|}{ Dependent variable: Reserve-to-GDP } \\
\hline & (1) & $(2)$ & (3) & (4) & (5) & (6) \\
\hline Equity Premium & $\begin{array}{c}0.660^{* * *} \\
(0.238)\end{array}$ & $\begin{array}{c}0.690^{* * *} \\
(0.200)\end{array}$ & $\begin{array}{c}0.659^{* * *} \\
(0.210)\end{array}$ & $\begin{array}{c}0.737^{* * *} \\
(0.191)\end{array}$ & $\begin{array}{c}0.574^{* * *} \\
(0.202)\end{array}$ & $\begin{array}{c}0.636^{* * *} \\
(0.180)\end{array}$ \\
\hline Openness & & $\begin{array}{c}0.219^{* * *} \\
(0.025)\end{array}$ & $\begin{array}{c}0.218^{* * *} \\
(0.025)\end{array}$ & $\begin{array}{c}0.170^{* * *} \\
(0.033)\end{array}$ & $\begin{array}{c}0.225^{* * *} \\
(0.024)\end{array}$ & $\begin{array}{c}0.171^{* * *} \\
(0.028)\end{array}$ \\
\hline Debt-to-GDP & & & $\begin{array}{l}-0.020 \\
(0.047)\end{array}$ & $\begin{array}{l}-0.019 \\
(0.033)\end{array}$ & $\begin{array}{l}-0.013 \\
(0.042)\end{array}$ & $\begin{array}{l}-0.019 \\
(0.028)\end{array}$ \\
\hline M2-to-GDP & & & & $\begin{array}{c}0.101^{* * *} \\
(0.026)\end{array}$ & & $\begin{array}{c}0.110^{* * *} \\
(0.024)\end{array}$ \\
\hline FX Regime & & & & & $\begin{array}{l}0.065^{* *} \\
(0.025)\end{array}$ & $\begin{array}{c}0.072^{* * *} \\
(0.022)\end{array}$ \\
\hline Constant & $\begin{array}{c}0.157^{* * *} \\
(0.020)\end{array}$ & $\begin{array}{c}-0.041^{*} \\
(0.023)\end{array}$ & $\begin{array}{l}-0.027 \\
(0.035)\end{array}$ & $\begin{array}{c}-0.064^{* *} \\
(0.031)\end{array}$ & $\begin{array}{c}-0.069^{*} \\
(0.037)\end{array}$ & $\begin{array}{c}-0.104^{* * *} \\
(0.032)\end{array}$ \\
\hline Country Fixed Effect & No & No & No & No & No & No \\
\hline Observations & 84 & 84 & 84 & 76 & 84 & 76 \\
\hline Number of countries & 42 & 42 & 42 & 38 & 42 & 38 \\
\hline $\mathrm{R}^{2}$ & 0.060 & 0.641 & 0.642 & 0.738 & 0.663 & 0.761 \\
\hline Adjusted $\mathrm{R}^{2}$ & 0.049 & 0.632 & 0.628 & 0.723 & 0.645 & 0.744 \\
\hline F Statistic & $5.259^{* *}$ & $72.177^{* * *}$ & $47.758^{* * *}$ & $49.899^{* * *}$ & $38.774^{* * *}$ & $44.545^{* * *}$ \\
\hline
\end{tabular}

Note: Robust standard errors are reported in parentheses. ${ }^{*} \mathrm{p}<0.1 ;{ }^{* *} \mathrm{p}<0.05 ;{ }^{* * *} \mathrm{p}<0.01$. 
Table B.4: Panel Fixed Effect Regressions with 3 windows

\begin{tabular}{lcccccc}
\hline \hline & & \multicolumn{5}{c}{ Dependent variable: Reserve-to-GDP } \\
& $(1)$ & $(2)$ & $(3)$ & $(4)$ & $(5)$ & $(6)$ \\
\hline Equity Premium & $0.261^{* * *}$ & $0.315^{* * *}$ & $0.285^{* *}$ & $0.369^{* * *}$ & $0.229^{* *}$ & $0.307^{* * *}$ \\
& $(0.092)$ & $(0.096)$ & $(0.111)$ & $(0.098)$ & $(0.109)$ & $(0.098)$ \\
Openness & & $0.216^{* * *}$ & $0.215^{* * *}$ & $0.165^{* * *}$ & $0.222^{* * *}$ & $0.169^{* * *}$ \\
& & $(0.021)$ & $(0.020)$ & $(0.027)$ & $(0.019)$ & $(0.024)$ \\
Debt-to-GDP & & & -0.034 & -0.037 & -0.024 & -0.033 \\
& & & $(0.044)$ & $(0.034)$ & $(0.040)$ & $(0.030)$ \\
M2-to-GDP & & & & $0.105^{* * *}$ & & $0.109^{* * *}$ \\
& & & & $(0.025)$ & & $(0.023)$ \\
FX Regime & & & & & $0.066^{* * *}$ & $0.072^{* * *}$ \\
& & & & & $(0.023)$ & $(0.022)$ \\
\hline Country Fixed Effect & Yes & Yes & Yes & Yes & Yes & Yes \\
Observations & 126 & 126 & 126 & 113 & 126 & 113 \\
Number of countries & 42 & 42 & 42 & 38 & 42 & 38 \\
$\mathrm{R}^{2}$ & 0.017 & 0.601 & 0.604 & 0.691 & 0.624 & 0.713 \\
Adjusted R & & & & & & \\
F Statistic & -0.007 & 0.587 & 0.587 & 0.673 & 0.605 & 0.694 \\
\hline \hline
\end{tabular}

Note: All specifications include country and time fixed effects. Robust standard errors clustered by country are reported in parentheses. ${ }^{*} \mathrm{p}<0.1 ;{ }^{* *} \mathrm{p}<0.05 ;{ }^{* * *} \mathrm{p}<0.01$. 


\section{C}

\section{Panel Regressions in Restricted Sample}

In this section, we present the panel regressions excluding the outliers of our sample, which are Greece, Hong Kong, Ireland, Singapore and Switzerland. We show that the results remain robust and in line with the previous results including all the countries, or even stronger in some specifications. The following figure displays the international reserves and the equity premium for the entire sample, which helps visualize the outliers.

Figure C.1: International Reserves and Equity Premium - All Countries

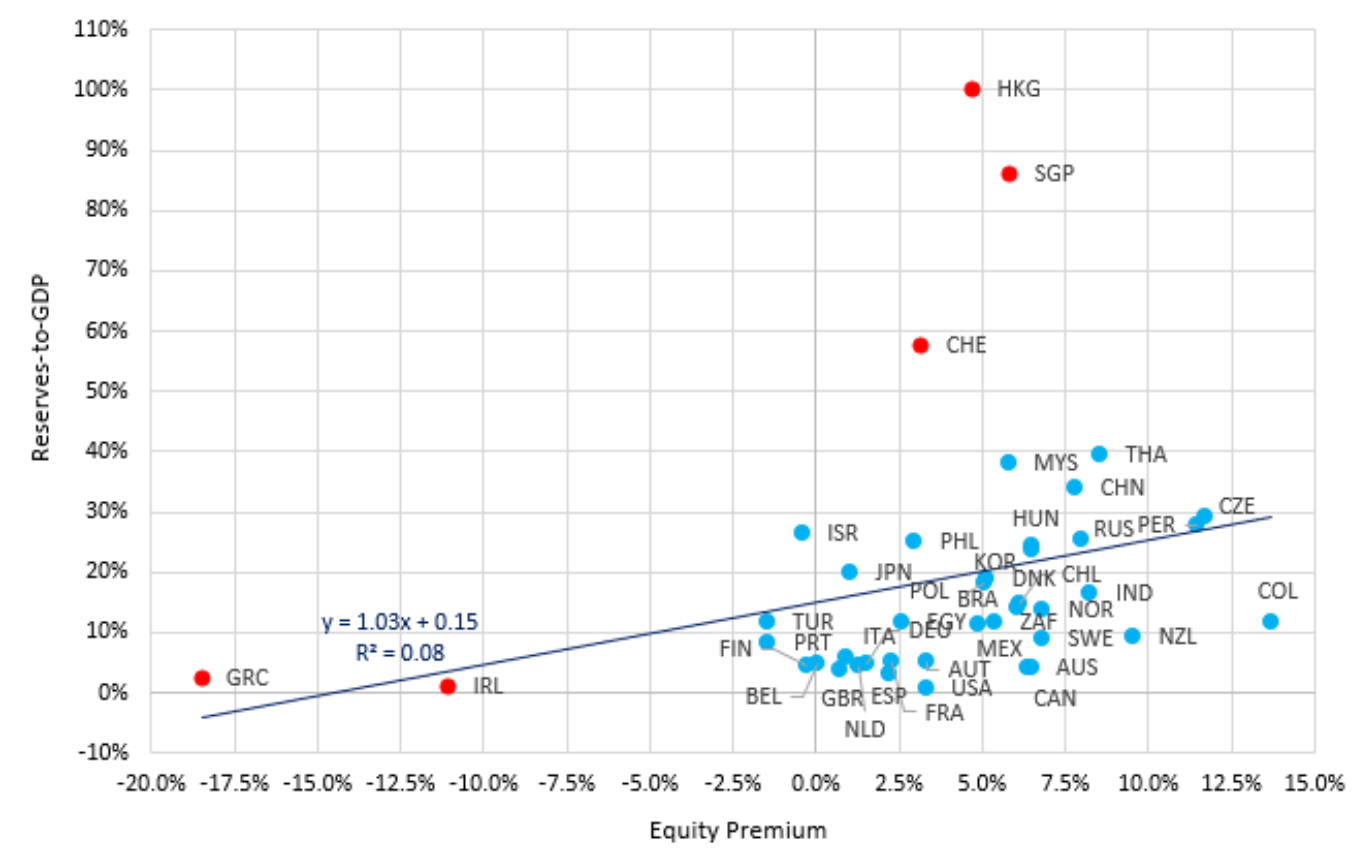


Table C.1: Panel Fixed Effect Regressions with Annual Data excluding outliers

\begin{tabular}{|c|c|c|c|c|c|}
\hline & \multicolumn{5}{|c|}{ Dependent variable: Reserve-to-GDP } \\
\hline & (1) & (2) & (3) & $(4)$ & (5) \\
\hline \multirow[t]{2}{*}{ Equity Premium } & $0.018^{*}$ & $0.022^{* *}$ & $0.021^{* *}$ & $0.026^{* *}$ & 0.014 \\
\hline & $(0.009)$ & $(0.009)$ & $(0.009)$ & $(0.010)$ & $(0.009)$ \\
\hline \multirow[t]{2}{*}{ Openness } & & $0.106^{* * *}$ & $0.107^{* * *}$ & $0.095^{* * *}$ & $0.107^{* * *}$ \\
\hline & & $(0.013)$ & $(0.013)$ & $(0.016)$ & $(0.013)$ \\
\hline \multirow[t]{2}{*}{ Debt-to-GDP } & & & $-0.038^{* * *}$ & $-0.058^{* * *}$ & $-0.050^{* * *}$ \\
\hline & & & $(0.010)$ & $(0.013)$ & $(0.013)$ \\
\hline \multirow[t]{2}{*}{ GDP cycle } & & & -0.011 & -0.019 & -0.015 \\
\hline & & & $(0.015)$ & $(0.018)$ & $(0.015)$ \\
\hline \multirow[t]{2}{*}{ M2-to-GDP } & & & & $0.080^{* * *}$ & \\
\hline & & & & $(0.013)$ & \\
\hline \multirow[t]{2}{*}{ FX Regime } & & & & & $0.031^{* * *}$ \\
\hline & & & & & $(0.010)$ \\
\hline Country Fixed Effect & Yes & Yes & Yes & Yes & Yes \\
\hline Observations & 696 & 696 & 696 & 606 & 623 \\
\hline Number of countries & 37 & 37 & 37 & 33 & 37 \\
\hline $\mathrm{R}^{2}$ & 0.005 & 0.142 & 0.155 & 0.215 & 0.162 \\
\hline Adjusted $\mathrm{R}^{2}$ & -0.023 & 0.116 & 0.128 & 0.184 & 0.132 \\
\hline F Statistic & $3.608^{*}$ & $55.767^{* * *}$ & $30.976^{* * *}$ & $31.828^{* * *}$ & $23.184^{* * *}$ \\
\hline
\end{tabular}

Note: All specifications include country and time fixed effects. Robust standard errors clustered by country are reported in parentheses. ${ }^{*} \mathrm{p}<0.1 ;{ }^{* *} \mathrm{p}<0.05 ;{ }^{* * *} \mathrm{p}<0.01$

Table C.2: Panel Fixed Effect Regressions with 3 windows excluding outliers

\begin{tabular}{lcccccc}
\hline \hline & \multicolumn{5}{c}{ Dependent variable: Reserve-to-GDP } \\
& $(1)$ & $(2)$ & $(3)$ & $(4)$ & $(5)$ & $(6)$ \\
\hline Equity Premium & $0.167^{*}$ & $0.187^{* *}$ & 0.144 & $0.203^{* *}$ & 0.124 & $0.175^{*}$ \\
& $(0.089)$ & $(0.087)$ & $(0.090)$ & $(0.094)$ & $(0.087)$ & $(0.089)$ \\
Openness & & $0.098^{* * *}$ & $0.091^{* * *}$ & $0.071^{* *}$ & $0.109^{* * *}$ & $0.089^{* *}$ \\
& & $(0.034)$ & $(0.033)$ & $(0.034)$ & $(0.035)$ & $(0.036)$ \\
Debt-to-GDP & & & -0.052 & $-0.096^{* * *}$ & -0.040 & $-0.086^{* *}$ \\
& & & $(0.039)$ & $(0.036)$ & $(0.039)$ & $(0.037)$ \\
M2-to-GDP & & & & $0.106^{* * *}$ & & $0.104^{* * *}$ \\
& & & & $(0.029)$ & & $(0.031)$ \\
FX Regime & & & & & $0.040^{*}$ & $0.044^{* *}$ \\
& & & & & $(0.023)$ & $(0.020)$ \\
\hline Country Fixed Effect & Yes & Yes & Yes & Yes & Yes & Yes \\
Observations & 111 & 111 & 111 & 98 & 111 & 98 \\
Number of countries & 37 & 37 & 37 & 33 & 37 & 33 \\
$\mathrm{R}^{2}$ & 0.020 & 0.128 & 0.154 & 0.308 & 0.182 & 0.341 \\
Adjusted R & -0.007 & 0.096 & 0.114 & 0.262 & 0.135 & 0.290 \\
F Statistic & 2.183 & $7.810^{* * *}$ & $6.390^{* * *}$ & $10.112^{* * *}$ & $5.795^{* * *}$ & $9.314^{* * *}$ \\
\hline \hline
\end{tabular}

Note: All specifications include country and time fixed effects. Robust standard errors clustered by country are reported in parentheses. ${ }^{*} \mathrm{p}<0.1 ;{ }^{* *} \mathrm{p}<0.05 ;{ }^{* * *} \mathrm{p}<0.01$. 
Table C.3: Panel Pooled OLS Regressions with 3 windows excluding outliers

\begin{tabular}{|c|c|c|c|c|c|c|}
\hline & \multicolumn{6}{|c|}{ Dependent variable: Reserve-to-GDP } \\
\hline & (1) & $(2)$ & (3) & (4) & (5) & (6) \\
\hline \multirow[t]{2}{*}{ Equity Premium } & $0.155^{*}$ & $0.175^{*}$ & 0.137 & $0.211^{* *}$ & 0.118 & $0.189^{* *}$ \\
\hline & $(0.093)$ & $(0.093)$ & $(0.096)$ & $(0.096)$ & $(0.091)$ & $(0.091)$ \\
\hline \multirow[t]{2}{*}{ Openness } & & $0.098^{* * *}$ & $0.094^{* * *}$ & $0.084^{* *}$ & $0.113^{* * *}$ & $0.099^{* * *}$ \\
\hline & & $(0.034)$ & $(0.034)$ & $(0.033)$ & $(0.035)$ & $(0.034)$ \\
\hline \multirow[t]{2}{*}{ Debt-to-GDP } & & & -0.045 & $-0.081^{* *}$ & -0.034 & $-0.073^{* *}$ \\
\hline & & & $(0.040)$ & $(0.036)$ & $(0.039)$ & $(0.035)$ \\
\hline \multirow[t]{2}{*}{ M2-to-GDP } & & & & $0.102^{* * *}$ & & $0.101^{* * *}$ \\
\hline & & & & $(0.029)$ & & $(0.032)$ \\
\hline \multirow[t]{2}{*}{ FX Regime } & & & & & $0.046^{*}$ & $0.043^{* *}$ \\
\hline & & & & & $(0.023)$ & $(0.019)$ \\
\hline \multirow[t]{2}{*}{ Constant } & $0.135^{* * *}$ & $0.062^{* *}$ & $0.094^{* * *}$ & 0.053 & 0.049 & 0.017 \\
\hline & $(0.010)$ & $(0.025)$ & $(0.035)$ & $(0.038)$ & $(0.049)$ & $(0.044)$ \\
\hline Country Fixed Effect & No & No & No & No & No & No \\
\hline Observations & 111 & 111 & 111 & 98 & 111 & 98 \\
\hline Number of countries & 37 & 37 & 37 & 33 & 37 & 33 \\
\hline $\mathrm{R}^{2}$ & 0.017 & 0.127 & 0.148 & 0.304 & 0.186 & 0.338 \\
\hline Adjusted $\mathrm{R}^{2}$ & 0.008 & 0.111 & 0.124 & 0.274 & 0.155 & 0.302 \\
\hline F Statistic & 1.899 & $7.847^{* * *}$ & $6.184^{* * *}$ & $10.148^{* * *}$ & $6.051^{* * *}$ & $9.388^{* * *}$ \\
\hline
\end{tabular}

Note: Robust standard errors are reported in parentheses. ${ }^{*} \mathrm{p}<0.1 ;{ }^{* *} \mathrm{p}<0.05 ;{ }^{* * *} \mathrm{p}<0.01$.

Table C.4: Panel Fixed Effect Regressions with 2 windows excluding outliers

\begin{tabular}{lcccccc}
\hline \hline & & \multicolumn{5}{c}{ Dependent variable: Reserve-to-GDP } \\
& $(1)$ & $(2)$ & $(3)$ & $(4)$ & $(5)$ & $(6)$ \\
\hline Equity Premium & $0.525^{* * *}$ & $0.531^{* * *}$ & $0.497^{* * *}$ & $0.603^{* * *}$ & $0.459^{* * *}$ & $0.543^{* * *}$ \\
& $(0.176)$ & $(0.161)$ & $(0.173)$ & $(0.182)$ & $(0.173)$ & $(0.182)$ \\
Openness & & $0.094^{* *}$ & $0.092^{* *}$ & $0.079^{* *}$ & $0.108^{* *}$ & $0.095^{* *}$ \\
& & $(0.039)$ & $(0.039)$ & $(0.038)$ & $(0.041)$ & $(0.038)$ \\
Debt-to-GDP & & & -0.023 & $-0.066^{*}$ & -0.018 & $-0.064^{*}$ \\
& & & $(0.043)$ & $(0.037)$ & $(0.042)$ & $(0.036)$ \\
M2-to-GDP & & & & $0.099^{* * *}$ & & $0.100^{* * *}$ \\
& & & & $(0.029)$ & & $(0.032)$ \\
FX Regime & & & & & 0.036 & $0.039^{*}$ \\
& & & & & $(0.026)$ & $(0.022)$ \\
\hline Country Fixed Effect & Yes & Yes & Yes & Yes & Yes & Yes \\
Observations & 74 & 74 & 74 & 66 & 74 & 66 \\
Number of countries & 37 & 37 & 37 & 33 & 37 & 33 \\
$\mathrm{R}^{2}$ & 0.096 & 0.201 & 0.207 & 0.384 & 0.228 & 0.409 \\
Adjusted R & & & & & & \\
F Statistic & 0.071 & 0.167 & 0.161 & 0.333 & 0.172 & 0.349 \\
\hline
\end{tabular}

Note: All specifications include country and time fixed effects. Robust standard errors clustered by country are reported in parentheses. ${ }^{*} \mathrm{p}<0.1 ;{ }^{* *} \mathrm{p}<0.05 ;{ }^{* * *} \mathrm{p}<0.01$. 
Table C.5: Panel Pooled OLS Regressions with 2 windows excluding outliers

\begin{tabular}{lcccccc}
\hline \hline & & \multicolumn{5}{c}{ Dependent variable: Reserve-to-GDP } \\
& $(1)$ & $(2)$ & $(3)$ & $(4)$ & $(5)$ & $(6)$ \\
\hline Equity Premium & $0.526^{* * *}$ & $0.532^{* * *}$ & $0.490^{* * *}$ & $0.599^{* * *}$ & $0.454^{* * *}$ & $0.557^{* * *}$ \\
& $(0.179)$ & $(0.166)$ & $(0.177)$ & $(0.181)$ & $(0.171)$ & $(0.176)$ \\
Openness & & $0.219^{* * *}$ & $0.092^{* *}$ & $0.079^{* *}$ & $0.109^{* *}$ & $0.093^{* *}$ \\
& & $(0.040)$ & $(0.040)$ & $(0.038)$ & $(0.041)$ & $(0.038)$ \\
Debt-to-GDP & & & -0.028 & $-0.067^{*}$ & -0.020 & $-0.061^{*}$ \\
& & & $(0.044)$ & $(0.037)$ & $(0.042)$ & $(0.036)$ \\
M2-to-GDP & & & & $0.099^{* * *}$ & & $0.099^{* * *}$ \\
& & & & $(0.029)$ & & $(0.033)$ \\
FX Regime & & & & & 0.039 & $0.035^{*}$ \\
& & & & & $(0.026)$ & $(0.020)$ \\
Constant & $0.118^{* * *}$ & 0.048 & $0.069^{*}$ & 0.031 & 0.032 & 0.001 \\
& $(0.012)$ & $(0.029)$ & $(0.040)$ & $(0.040)$ & $(0.054)$ & $(0.044)$ \\
\hline Country Fixed Effect & No & No & No & No & No & No \\
Observations & 74 & 74 & 74 & 66 & 74 & 66 \\
Number of countries & 37 & 37 & 37 & 33 & 37 & 33 \\
$\mathrm{R}^{2}$ & 0.095 & 0.200 & 0.209 & 0.386 & 0.236 & 0.410 \\
Adjusted R & & & & & & \\
F Statistic & 0.082 & 0.178 & 0.175 & 0.346 & 0.192 & 0.360 \\
\hline \hline
\end{tabular}

Note: Robust standard errors are reported in parentheses. ${ }^{*} \mathrm{p}<0.1 ;{ }^{* *} \mathrm{p}<0.05 ;{ }^{* * *} \mathrm{p}<0.01$.

Table C.6: Pure Cross-Section Regressions excluding outliers

\begin{tabular}{|c|c|c|c|c|c|c|}
\hline & \multicolumn{6}{|c|}{ Dependent variable: Reserve-to-GDP } \\
\hline & (1) & (2) & $(3)$ & (4) & (5) & (6) \\
\hline \multirow[t]{2}{*}{ Equity Premium } & $1.244^{* * *}$ & $1.255^{* * *}$ & $1.305^{* * *}$ & $1.693^{* * *}$ & $1.475^{* * *}$ & $1.612^{* * *}$ \\
\hline & $(0.424)$ & $(0.407)$ & $(0.470)$ & $(0.482)$ & $(0.461)$ & $(0.477)$ \\
\hline \multirow[t]{2}{*}{ Openness } & & $0.087^{*}$ & $0.088^{*}$ & 0.066 & $0.110^{*}$ & $0.075^{*}$ \\
\hline & & $(0.048)$ & $(0.048)$ & $(0.041)$ & $(0.054)$ & $(0.040)$ \\
\hline \multirow{2}{*}{ Debt-to-GDP } & & & 0.011 & -0.029 & 0.016 & -0.027 \\
\hline & & & $(0.059)$ & $(0.046)$ & $(0.060)$ & $(0.043)$ \\
\hline \multirow[t]{2}{*}{ M2-to-GDP } & & & & $0.115^{* * *}$ & & $0.116^{* * *}$ \\
\hline & & & & $(0.028)$ & & $(0.032)$ \\
\hline \multirow[t]{2}{*}{ FX Regime } & & & & & 0.028 & 0.030 \\
\hline & & & & & $(0.036)$ & $(0.026)$ \\
\hline \multirow[t]{2}{*}{ Constant } & $0.088^{* * *}$ & 0.024 & 0.014 & -0.042 & -0.023 & -0.062 \\
\hline & $(0.022)$ & $(0.040)$ & $(0.062)$ & $(0.061)$ & $(0.074)$ & $(0.057)$ \\
\hline Country Fixed Effect & No & No & No & No & No & No \\
\hline Observations & 37 & 37 & 37 & 33 & 37 & 33 \\
\hline Number of countries & 37 & 37 & 37 & 33 & 37 & 33 \\
\hline $\mathrm{R}^{2}$ & 0.198 & 0.283 & 0.283 & 0.525 & 0.414 & 0.539 \\
\hline Adjusted $\mathrm{R}^{2}$ & 0.175 & 0.240 & 0.218 & 0.457 & 0.331 & 0.453 \\
\hline F Statistic & $8.625^{* * *}$ & $6.696^{* * *}$ & $4.350^{* *}$ & $7.736^{* * *}$ & $4.953^{* * *}$ & $6.309^{* * *}$ \\
\hline
\end{tabular}

Note: Robust standard errors are reported in parentheses. ${ }^{*} \mathrm{p}<0.1 ;{ }^{* *} \mathrm{p}<0.05 ;{ }^{* * *} \mathrm{p}<0.01$. 